\title{
Nuclear poly(ADP-ribose) activity is a therapeutic target in amyotrophic lateral sclerosis
}

\author{
L. McGurk', J. Mojsilovic-Petrovic ${ }^{2,3}$, V. M. Van Deerlin ${ }^{4}$, J. Shorter ${ }^{5}$, R. G. Kalb ${ }^{2,3}$, V. M. Lee ${ }^{4}$, J. Q. Trojanowski ${ }^{4}$, \\ E. B. Lee ${ }^{4,6}$ and N. M. Bonini ${ }^{1 *}$
}

\begin{abstract}
Amyotrophic lateral sclerosis (ALS) is a devastating and fatal motor neuron disease. Diagnosis typically occurs in the fifth decade of life and the disease progresses rapidly leading to death within $\sim 2-5$ years of symptomatic onset. There is no cure, and the few available treatments offer only a modest extension in patient survival. A protein central to ALS is the nuclear RNA/DNA-binding protein, TDP-43. In $>95 \%$ of ALS patients, TDP-43 is cleared from the nucleus and forms phosphorylated protein aggregates in the cytoplasm of affected neurons and glia. We recently defined that poly(ADP-ribose) (PAR) activity regulates TDP-43-associated toxicity. PAR is a posttranslational modification that is attached to target proteins by PAR polymerases (PARPs). PARP-1 and PARP-2 are the major enzymes that are active in the nucleus. Here, we uncovered that the motor neurons of the ALS spinal cord were associated with elevated nuclear PAR, suggesting elevated PARP activity. Veliparib, a small-molecule inhibitor of nuclear PARP-1/2, mitigated the formation of cytoplasmic TDP-43 aggregates in mammalian cells. In primary spinal-cord cultures from rat, Veliparib also inhibited TDP-43-associated neuronal death. These studies uncover that PAR activity is misregulated in the ALS spinal cord, and a small-molecular inhibitor of PARP-1/2 activity may have therapeutic potential in the treatment of ALS and related disorders associated with abnormal TDP-43 homeostasis.
\end{abstract}

Keywords: ABT-888/Neliparib, Parp, Poly(ADP-ribose), PAR, PARylation, Motor neuron disease, primary neuron, TDP-43

\section{Introduction}

Amyotrophic lateral sclerosis (ALS) is a fatal neurodegenerative disease where the degeneration of upper and lower motor neurons leads to muscle atrophy, paralysis and death typically within $\sim 2-5$ years of disease onset [47]. In $>95 \%$ of ALS patients, the normally nuclear protein TDP-43 redistributes to the cytoplasm and forms phosphorylated aggregates in affected neurons and glia $[45,69,84,85]$. The treatment options for ALS are bleak, most are palliative and address the well-being and comfort of the patient $[38,44,82,91]$. The first FDA-approved drug was riluzole, an anti-glutamatergic that provides $\mathrm{a} \sim 2-3$-month extension in patient survival $[88,95]$. In the 20 years since, a gamut of

\footnotetext{
* Correspondence: nbonini@sas.upenn.edu

'Department of Biology, University of Pennsylvania, Philadelphia, PA 19104, USA

Full list of author information is available at the end of the article
}

treatments has been clinically tested, but most have failed to demonstrate therapeutic efficacy $[9,38,88]$. In 2017, the second FDA approval was granted to edaravone, an anti-oxidant which, when administered with riluzole, modestly reduces neurological decline in the early stages of disease [26, 39, 40, 92, 97]. Thus, uncovering molecular pathways that contribute to the decline and loss of motor neurons in ALS is imperative for the development and testing of new treatments.

Although the exact cause of ALS remains largely unknown, genetic factors contribute to $\sim 5-10 \%$ of cases $[65,107]$. Familial genes include SOD1, C9orf72, ATXN2 and TARDBP $[28,29,89,90,104]$. Several of the proteins mutated in ALS, including TDP-43 and Ataxin-2, are components of cytoplasmic stress granules [64], which are membraneless organelles that are comprised of translationally-arrested mRNA and associated proteins $[4,53]$. In the ALS spinal cord, several stress-granule

(c) The Author(s). 2018 Open Access This article is distributed under the terms of the Creative Commons Attribution 4.0 International License (http://creativecommons.org/licenses/by/4.0/), which permits unrestricted use, distribution, and 
proteins, such as TIA-1, eIF3, and PABPC-1, co-aggregate with phosphorylated TDP-43 inclusions [10, 66, 74]. Furthermore, manipulation of proteins that regulate the stress response is beneficial in animal and cellular models of ALS [8, 29, 35, 55, 58, 86, 98, 117]. Despite evidence implicating stress pathways in ALS, it is unclear whether they are cause or consequence of the disease process.

We identified Tankyrase, a poly(ADP-ribose) polymerase, or PARP, as a potent regulator of disease-associated features of TDP-43 in Drosophila and mammalian cell models of ALS [73]. PARPs are enzymes that catabolize $\mathrm{NAD}^{+}$to sequentially add ADP-ribose subunits onto target proteins, generating polymers of poly(ADP-ribose) (PAR) [37]. PAR activity is often stress responsive and can serve as an upstream signaling molecule [41, 63, 68]. In mammals, the PARP superfamily consists of 17 enzymes, with the most abundant and well characterized being PARP-1 [67, 99]. In the nucleus, PARP-1 and PARP-2 regulate DNA damage, gene expression, and cell survival [18, 34, 41, 48, 67]. Here, we report that PAR levels are elevated in the nuclei of motor neurons in the spinal cord of ALS patients, and that a PARP-1/2 inhibitor is therapeutic in a rodent spinal-cord cellular model of TDP-43-associated toxicity. These findings implicate an alteration in PAR activity in ALS, and suggest that PARP-1/2 inhibitors, which are in use for cancer treatment, might be repurposed for TDP-43-associated disorders.

\section{Materials and methods}

\section{Clinical data and patient consent}

Patient tissue was obtained from the Center for Neurodegenerative Disease Research (CNDR) Brain Bank at the University of Pennsylvania, brief details are provided in Tables 1 and 2. Patients were selected on the basis of having phosphorylated TDP-43 in motor neurons in the spinal cord. All patients pre-consented for autopsy as well as at time of death. Consent for autopsy was re-obtained from the next-of-kin in accordance with institutional review board guidelines of the University of Pennsylvania. The University of Pennsylvania Institutional Review Board reviewed and confirmed that the CNDR Neurodegenerative Disease Autopsy Brain Bank protocols meet the criteria for human-subjects research.

\section{Immunohistochemistry}

Tissue was examined by routine neuropathologic diagnostic methods, as described [36, 83, 85, 110]. Briefly, spinal-cord regions were fixed in $10 \%$ neutral buffered formalin and $6 \mu \mathrm{m}$ thick sections were cut from paraffin-embedded tissue. After dewaxing and rehydration endogenous peroxidases were quenched in 30\% $\mathrm{H}_{2} \mathrm{O}_{2}$ made up in methanol (30 min) and washed in running tap water $(10 \mathrm{~min})$. For antibodies requiring antigen retrieval (only anti-phosphorylated TDP-43) slides were incubated in a citrate based antigen retrieval ( $\mathrm{pH} 6)$ buffer (Vector labs \#H3300) (15 $\mathrm{min}$ at $99{ }^{\circ} \mathrm{C}$ ) in an EZ-retriever microwave (BioGenex). Slides and solution

Table 1 Patients with no known neurological disease

\begin{tabular}{|c|c|c|c|c|c|c|c|c|c|c|}
\hline$\#$ & Diagnosis & Sex & Age at Death (yr) & PMI (hr) & Brain weight (g) & ALS stage & Braak stage & Thal phase & CERAD & $\angle B D$ \\
\hline 1 & normal & $M$ & 47 & 12 & 1383 & 0 & $|/| \mid$ & 0 & 0 & no \\
\hline 2 & normal & $M$ & 70 & 10.5 & 1388 & 0 & $|/| \mid$ & 1 & 0 & no \\
\hline 3 & normal & $\mathrm{F}$ & 72 & 7 & 1406 & 0 & $|/| \mid$ & 0 & 0 & no \\
\hline 4 & normal & $\mathrm{F}$ & 65 & 19 & 1207 & 0 & 0 & 1 & 0 & no \\
\hline 5 & normal & $\mathrm{F}$ & 56 & 12 & 1416 & 0 & $|/| \mid$ & $\mathrm{n} / \mathrm{a}$ & 0 & no \\
\hline 6 & normal & $M$ & 61 & 6 & 1369 & 0 & 0 & 1 & 0 & no \\
\hline 7 & normal & M & 55 & 11.5 & 1448 & 0 & 0 & $\mathrm{n} / \mathrm{a}$ & 0 & no \\
\hline 8 & normal & $\mathrm{F}$ & 59 & 13 & 1166 & 0 & 0 & $\mathrm{n} / \mathrm{a}$ & 0 & no \\
\hline 9 & normal & $M$ & 68 & 21 & 1330 & 0 & $|/| \mid$ & 0 & 0 & no \\
\hline 10 & normal & M & 47 & 11 & 1333 & 0 & $|/| \mid$ & $\mathrm{n} / \mathrm{a}$ & A & no \\
\hline 11 & normal & $M$ & 72 & 13.5 & 1320 & 0 & $|/| \mid$ & 3 & A & no \\
\hline 12 & normal & $\mathrm{F}$ & 46 & 12 & 1228 & 0 & 0 & $\mathrm{n} / \mathrm{a}$ & 0 & no \\
\hline 13 & normal & $\mathrm{F}$ & 65 & 22 & 1206 & 0 & $|/| \mid$ & 1 & 0 & no \\
\hline 14 & normal & $M$ & 67 & 15 & 1545 & 0 & $|/| \mid$ & 2 & A & no \\
\hline 15 & normal & $\mathrm{F}$ & 68 & 15 & 1151 & 0 & $|/| \mid$ & 0 & 0 & no \\
\hline 16 & normal & $M$ & 70 & 36 & 1755 & 0 & 0 & 0 & 0 & no \\
\hline
\end{tabular}

Abbreviations: \#: case number, Normal diagnosed neurologically normal, $F$ female, $M$ male, $P M I$ postmortem interval, ALS stage stages $0-4$ semiquantitatively assessed according to [14, 15]. Braak stage neurofibrillary tangle deposition according to [12, 13]. Thal phase amyloid deposition according to [108]. CERAD neuritic plaque deposition according to [76, 80]. LBD Lewy Body disease according to [75]. n/a data not available. no no LBD 
Table 2 Details of patients diagnosed with ALS-related neurological disease

\begin{tabular}{|c|c|c|c|c|c|c|c|c|c|c|c|c|c|}
\hline$\#$ & Diagnosis & Sex & $\begin{array}{l}\text { Age of } \\
\text { Onset (yr) }\end{array}$ & $\begin{array}{l}\text { Age at } \\
\text { Death (yr) }\end{array}$ & $\begin{array}{l}\text { Disease } \\
\text { Duration (yr) }\end{array}$ & $\begin{array}{l}\text { Mutation } \\
\text { Status }\end{array}$ & $\begin{array}{l}\text { PMl } \\
\text { (hr) }\end{array}$ & $\begin{array}{l}\text { Brain } \\
\text { weight (g) }\end{array}$ & $\begin{array}{l}\text { ALS } \\
\text { Stage }\end{array}$ & $\begin{array}{l}\text { Braak } \\
\text { stage }\end{array}$ & $\begin{array}{l}\text { Thal } \\
\text { phase }\end{array}$ & CERAD & LBD \\
\hline 17 & ALS & $M$ & 41 & 42 & 1 & - & 8 & 1554 & 2 & $|/| \mid$ & $\mathrm{n} / \mathrm{a}$ & 0 & no \\
\hline 18 & ALS & M & 71 & 76 & 5 & - & 23 & 1297 & 1 & $|/| \mid$ & $\mathrm{n} / \mathrm{a}$ & A & no \\
\hline 19 & ALS & M & 50 & 53 & 3 & - & 24 & 1422 & 2 & 0 & $\mathrm{n} / \mathrm{a}$ & 0 & no \\
\hline 20 & ALS-D & F & 50 & 51 & 1 & - & 4 & 1203 & 4 & |/II & $\mathrm{n} / \mathrm{a}$ & 0 & no \\
\hline 21 & ALS & M & 43 & 46 & 3 & - & 5 & 1427 & 3 & $|/| \mid$ & $\mathrm{n} / \mathrm{a}$ & 0 & no \\
\hline 22 & ALS & $\mathrm{F}$ & 79 & 81 & 2 & - & 10 & 1215 & 4 & III/IV & $\mathrm{n} / \mathrm{a}$ & 0 & no \\
\hline 23 & ALS & M & 64 & 66 & 2 & - & 14 & 1427 & 2 & $|/| \mid$ & $\mathrm{n} / \mathrm{a}$ & 0 & no \\
\hline 24 & ALS & M & 76 & 85 & 9 & - & 9 & 1041 & 1 & VNI & $\mathrm{n} / \mathrm{a}$ & C & $\begin{array}{l}\text { diffuse } \\
\text { neocortical }\end{array}$ \\
\hline 25 & ALS & $\mathrm{F}$ & 73 & 75 & 2 & - & 8 & 1405 & 4 & |/II & $\mathrm{n} / \mathrm{a}$ & A & no \\
\hline 26 & ALS-D & $\mathrm{F}$ & 57 & 59 & 2 & - & 18 & 1125 & 4 & |/II & $\mathrm{n} / \mathrm{a}$ & 0 & no \\
\hline 27 & ALS/PLS & M & 54 & 74 & 20 & - & 4 & 1169 & 1 & |/II & $\mathrm{n} / \mathrm{a}$ & 0 & no \\
\hline 28 & ALS & M & 69 & 70 & 1 & - & 4 & 1135 & 1 & 0 & 0 & 0 & no \\
\hline 29 & ALS & $F$ & 63 & 67 & 4 & - & 10 & 1384 & 2 & 0 & 0 & 0 & no \\
\hline 30 & ALS & $\mathrm{F}$ & 43 & 50 & 7 & - & $\mathrm{n} / \mathrm{a}$ & 1237 & 2 & 0 & 0 & 0 & no \\
\hline 31 & ALS & $\mathrm{F}$ & $\mathrm{n} / \mathrm{a}$ & 48 & $\mathrm{n} / \mathrm{a}$ & ATXN2 (22/32) & 5 & 1374 & 3 & 0 & $\mathrm{n} / \mathrm{a}$ & 0 & no \\
\hline 32 & ALS-D & M & $\mathrm{n} / \mathrm{a}$ & 78 & $\mathrm{n} / \mathrm{a}$ & ATXN2 (22/27) & 6 & 1300 & 4 & III/IV & $\mathrm{n} / \mathrm{a}$ & B & transitional \\
\hline 33 & ALS & $\mathrm{F}$ & 64 & 67 & 3 & ATXN2 (20/31) & 19 & 1229 & 3 & |/II & $\mathrm{n} / \mathrm{a}$ & 0 & no \\
\hline 34 & ALS & M & 63 & 65 & 2 & ATXN2 (22/29) & 7 & 1395 & 4 & III/IV & $\mathrm{n} / \mathrm{a}$ & 0 & no \\
\hline 35 & ALS & $\mathrm{F}$ & 54 & 56 & 2 & ATXN2 (22/27) & 10 & 1426 & 1 & |/II & $\mathrm{n} / \mathrm{a}$ & 0 & no \\
\hline 36 & ALS & M & 52 & 54 & 2 & C9orf72 & 4 & 1536 & 3 & 0 & $\mathrm{n} / \mathrm{a}$ & 0 & no \\
\hline 37 & FTD & $\mathrm{F}$ & 47 & 54 & 7 & C9orf72 & 12 & 813 & 4 & III/IV & $\mathrm{n} / \mathrm{a}$ & 0 & no \\
\hline 38 & ALS-D & M & 55 & 57 & 2 & C9orf72 & 9 & 1200 & 4 & III/IV & $\mathrm{n} / \mathrm{a}$ & B & no \\
\hline 39 & ALS-D & M & 54 & 57 & 3 & C9orf72 & 15 & 1244 & $\mathrm{n} / \mathrm{a}$ & |/II & $\mathrm{n} / \mathrm{a}$ & 0 & no \\
\hline 40 & ALS-D & $F$ & 67 & 69 & 2 & C9orf72 & 21 & 1079 & 4 & III/IV & $\mathrm{n} / \mathrm{a}$ & B & no \\
\hline 41 & ALS-D & M & 61 & 62 & 1 & C9orf72 & 30 & 1240 & 4 & |/II & $\mathrm{n} / \mathrm{a}$ & 0 & no \\
\hline 42 & ALS-D & M & 46 & 48 & 2 & C9orf72 & 13 & 1309 & 4 & |/II & $\mathrm{n} / \mathrm{a}$ & 0 & no \\
\hline 43 & ALS & M & 70 & 71 & 1 & C9orf72 & 18 & 1221 & 2 & $\mathrm{~V} / \mathrm{NI}$ & 2 & B & no \\
\hline
\end{tabular}

Abbreviations: \#: case number. -: no known mutation in TARDBP, UBQLN2, ATXN2, and C9orf72. ATXN2 refers to an intermediate CAG-trinucleotide expansion in ATXN2 (pathologic repeat length is indicated in brackets). C9orf72 refers to a GGGGCC-hexanucleotide repeat expansion. ALS-D ALS with dementia, FTD frontotemporal degeneration, $P L S$ primary lateral sclerosis. $F$ female, $M$ male. $P M I$ postmortem interval. $A L S$ stage stages $0-4$ semiquantitatively assessed according to $[14,15]$. Braak stage neurofibrillary tangle deposition according to $[12,13]$. Thal phase amyloid deposition according to [108]. CERAD neuritic plaque deposition according to $[76,80]$. LBD Lewy Body disease according to [75]. $n / a$ data not available. no no LBD

were placed in a cool tray and left to cool to room temperature $(\sim 20 \mathrm{~min})$. Slides were washed in $0.1 \mathrm{M}$ Tris pH 7.6 and blocked in $0.1 \mathrm{M}$ Tris $\mathrm{pH} 7.6$ with $2 \%$ FBS. Primary antibodies, in $0.1 \mathrm{M}$ Tris $\mathrm{pH} 7.6$ with $2 \%$ FBS, were applied overnight at $4{ }^{\circ} \mathrm{C}$. Sections were

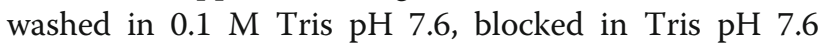
with $2 \% \mathrm{FBS}$, and incubated with biotinylated IgG from mouse ( 1 in 1000, Vector labs \#BA-2000) or rat (1 in 1000, Vector labs \#BA-9401) for $1 \mathrm{~h}$ at room temperature. Slides were washed in $0.1 \mathrm{M}$ Tris $\mathrm{pH} 7.6$ and then $0.1 \mathrm{M}$ Tris $\mathrm{pH} 7.6$ with $2 \%$ FBS and incubated with an avidin-conjugated horseradish peroxidase (Vectastain ABC kit, \#PK-6100) made up in Tris pH 7.6 with $2 \%$ FBS ( $1 \mathrm{~h}$ at room temperature). Slides were washed in Tris pH 7.6 and developed with Diaminiobenzidine (DAB) solution (Vector labs, SK-4105) for $8 \mathrm{~min}$ at room temperature. Slides were counterstained with Harris hematoxylin (30 s), washed in running tap water (10 min) dehydrated, cleared in xylene and mounted in cytoseal XYL (ThermoFisher, \#8312-4). All Tris based washes were $5 \mathrm{~min}$. Primary antibodies used were rat anti-phosphorylated (pS409/410) TDP-43 monoclonal antibody (1 in 500, [83]) and mouse anti-PAR, BSA free ( 1 in 500, Tulip Biolabs, \#1020 N). Note, antigen retrieval and cooling steps were omitted for anti-PAR labelling. The anti-PAR antibody was first optimized by a serial dilution test (from 1 in 400 to 1 in 25, 000). No signal was detected at 1 in 25,000 indicating that the 
secondary antibody was not contributing to the observed signal at higher primary concentrations. Dilution tests were performed on spinal cord tissue from 5 normal cases and 4 ALS cases.

Slides were coded and blinded and quantified by two researchers independently. For nuclear PAR scoring, 1-5 sections from every case were quantified and all the alpha motor neurons present in the anterior horns of each of section were scored for whether the nucleus was present and, if so, whether the nucleus stained for PAR. If all motor neurons with a nucleus were negative for PAR the score was 0 . If 1 or more motor neurons with nuclei visible in the section were present and stained for nuclear PAR: a score of + was given if nuclear PAR was present in 1 motor neuron and ++ if more than 1 motor neuron stained for nuclear PAR. To determine the number of alpha motor neurons in ALS and normal spinal cord, motor neurons from one anterior horn from each case were counted. In the ALS anterior horn, there were $13.7 \pm 1.4$ (SEM) alpha motor neurons with 4.0 \pm 0.4 (SEM) nuclei exposed. In the normal anterior horn, there were $19.5 \pm 1.4$ (SEM) alpha motor neurons with $5.6 \pm 0.6(\mathrm{SEM})$ nuclei exposed.

\section{Immunofluorescence and cell culture}

Human TDP-43-YFP cloned into pcDNA3.2 is described [29]. Standard cell culture and immunofluorescence techniques were used as described [73]. Briefly, COS-7 cells were maintained in Dulbecco's modified Eagle's medium (DMEM) containing high glucose and L-glutamine and sodium bicarbonate (Sigma-Aldrich, \#D5796. 10\% fetal bovine serum (Sigma-Aldrich, \#F6178) and 1\% penicillinstreptomycin (ThermoFisher, \#15140122) at $37{ }^{\circ} \mathrm{C}$ with $5 \% \mathrm{CO}_{2}$. For immunofluorescence cells were grown on glass coverslips coated with poly-L-lysine (NeuVitro, \#H-12-1.5-pll) and transfected with Lipofectamine LTX and PLUS reagent (ThermoFisher, \#15338100) in DMEM with $10 \%$ fetal bovine serum and no antibiotics. The transfection reaction was not removed and experiments were performed $21 \mathrm{~h}$ later. Veliparib (ABT-888, Selleckchem, \# S1004) experiments were performed by supplementing the media with the inhibitor, cells were pre-treated with Veliparib or DMSO for 90 min prior to stress. Cells were then incubated for $30 \mathrm{~min}$ with media supplemented with $0.25 \mathrm{mM}$ sodium arsenite and DMSO or Veliparib at the indicated concentration. Cells were fixed for $15 \mathrm{~min}$ in $4 \%$ paraformaldehyde, permeabilized in PEM buffer $(100 \mathrm{mM}$ PIPES, $1 \mathrm{mM} \mathrm{MgCl}_{2}$ and $10 \mathrm{mM}$ EGTA pH 6.8) supplemented with $0.1 \%$ triton X100 and then blocked in $10 \%$ normal donkey serum (Sigma-Aldrich). The primary antibody used was anti-mouse TIAR (1 in 500; BD Biosciences \#5137) and the secondary antibody was Alexa-Fluor-594 (1 in 500; ThermoFisher, \# A-21203). Coverslips were mounted in Prolong Diamond (ThermoFisher, \# P36965).
4-5 independent images were captured at 20X magnification and the percentage of cells with cytoplasmic YFP-positive foci or TIAR-labelled stress granules were quantified. Approximately five to ten images were captured per experiment and each experiment was performed at least three independent times. Statistics were carried out using Graphpad 6 software.

\section{Rat motor neuron cultures}

Mixed spinal cord cultures were prepared from rat and transfected with virus following previously established protocols $[77,78]$. The titer of herpes simplex virus routinely used in our studies was $3-5 \times 10^{7}$ plaque forming units $(\mathrm{pfu}) / \mathrm{ml}$ [78]. The primary neuron cultures were infected 14 days in vitro (DIV) with herpes simplex virus (HSV) expressing either TDP-43 or LacZ. The inhibitor Veliparib, also called ABT-888 (Selleckchem, \# S1004), or DMSO was added to the cell-culture medium at the indicated concentration at the time of infection. Media was changed 3-days post infection and cells were fixed and processed for immunofluorescence on day 5 of infection. Mouse anti-neurofilament-H, NF-H (1 in 1000, Biolegend \#801703) and mouse AlexaFluor 488 ( 1 in 500, ThermoFisher, \# A-21203) were used to identify neurons. Five images (10X magnification) were captured from each condition and remaining neuronal cell bodies were counted. Each condition was repeated three times, on three independent cultures. Statistics were performed in Graphpad 6 software.

\section{Statistics}

All data were analyzed in Graphpad Prism 6. To compare age at death between normal and ALS a Mann-Whitney Test was used. To compare disease duration between ALS disease cohorts a Kruskal-Wallis test was used. To compare cytoplasmic or nuclear PAR immunoreactivity between normal and ALS, or nuclear PAR between ALS and ALS-D cohorts a Fisher's exact test was used. To compare nuclear PAR immunoreactivity between ALS-no mut, ALS-ATXN2 and ALS- $c 9$, a Chi square $\left(X^{2}\right)$ test was used. Cell culture and primary neuron experiments were repeated in triplicate and a mean $( \pm$ SEM) is presented. One-way or two-way ANOVA followed by the appropriate post-hoc test was used to test for significance. Details of statistical tests used are in the associated figure legends. All experiments were repeated in triplicate unless otherwise stated. Data were considered statistically significant if $p \leq 0.05, p$ values are marked ${ }^{*}$ if $p \leq 0.05,{ }^{* *}$ if $p \leq 0.01, * * *$ if $p \leq 0.001$ and $* * * *$ if $p \leq 0.0001$.

\section{Results}

Study subjects, clinical characteristics and diagnosis We examined spinal cord tissue from a total of 43 patients; 16 were negative for any known neurological 
disorder (9 male and 7 female) and are described as the normal cohort (Fig. 1a and Table 1). As we wanted to analyze motor neurons and phosphorylated TDP-43 inclusions in the ALS spinal cord, we selected cases which had large alpha neurons that also contained phosphorylated TDP-43 inclusions. Of the 27 selected disease cases (16 male and 11 female), 17 were diagnosed with ALS, 8 with ALS concomitant with dementia (ALS-D), 1 with ALS concomitant with primary lateral sclerosis (PLS) and 1 with frontotemporal degeneration (FTD) (Fig. 1b and Table 2), and are collectively described as the ALS-cohort. The median age of onset for the disease cohort was 59 yr., the median disease duration was 2 yr. There was no significant difference in the median age at death between the normal and ALS cohorts (65 yr. vs 62 yr., respectively) (Fig. 1c). Of the ALS cohort, 14 were negative for known mutations in TARDBP, UBQLN2, FUS, $A T X N 2$ and $C 9$ orf72, 5 had an intermediate polyglutamine (polyQ) expansion (27-33 CAG repeats) in ATXN2 (ALS-ATXN2), and 8 cases had a G4C2-hexanucleotide repeat expansion in C9orf72 (ALS-c9) (Table 2). No data for disease onset was present for two ALS-ATXN2 cases. No significant difference was detected in this cohort for disease duration or age at death between ALS-no mut, ALS-ATXN2 and ALS-c9 (Fig. 1c-d).

\section{Nuclear PAR is elevated in motor neurons of ALS spinal cord}

To ascertain whether PAR activity was misregulated in disease, we examined the post-mortem spinal cord for immunoreactivity against PAR. We observed PAR in the nucleus and cytoplasm of motor neurons in spinal-cord tissue from both neurologically normal and ALS patients
(Fig. 2a). Tissue sections were coded and blinded and examined for the presence of PAR in the motor neurons of the anterior horn. The severity of neuropathological markers such as phosphorylated TDP-43 are routinely graded on a semi-quantitative scale $[14,15]$. We developed a semi-quantitative scale to score PAR immunoreactivity in motor neurons ( 0 not detectable; + detectable in 1 motor neuron; and ++ detectable in $>1$ motor neuron) and examined staining in both the cytoplasm and nucleus. Our analysis revealed that 12 out of 14 of the neurologically normal cases and 27 out of 27 ALS cases presented with PAR in the cytoplasm of motor neurons (Fig. 2a-b and Tables 3 and 4). A Fisher's exact test revealed no significant difference $(p=0.1329)$ between normal and ALS patients, indicating that cytoplasmic PAR was not significantly misregulated in this disease cohort. By contrast, nuclear PAR in the spinal cord motor neurons was detected in 3 out of 16 normal cases and in 24 out of 27 ALS cases (Fig. 2a and c, Tables 3 and 4). All cases that were negative for nuclear PAR presented with motor neurons with visible nuclei. A Fisher's exact test between the normal and ALS cases revealed that motor neurons with nuclear PAR was significantly $(p<0.0001)$ associated with ALS. Additionally, the presence of nuclear PAR in the motor neurons of the spinal cord from ALS-no mut, ALS-ATXN2 and ALS-c9orf72 did not differ $\left(X^{2}(3)=0.1436, p=0.9861\right)$ (Table 4). Given the reported morphological differences in TDP-43 aggregates in the anterior cingulate of ALS vs ALS-D patients [106], we compared nuclear PAR in the motor neurons between these two disease subtypes and observed no statistical significance $(p=1.0)$. It is important to note that the normal anterior horn compared to
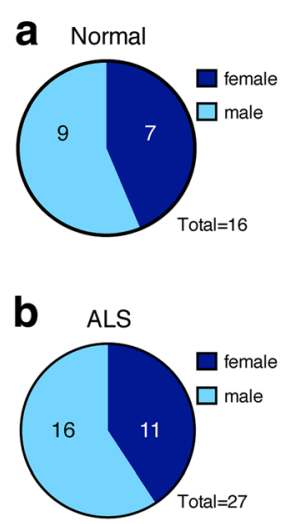

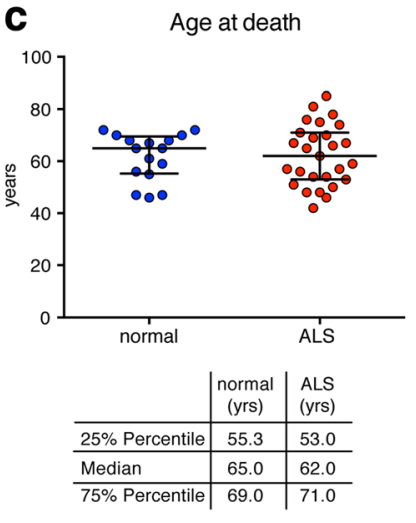

Mann-Whitney $p=0.94$

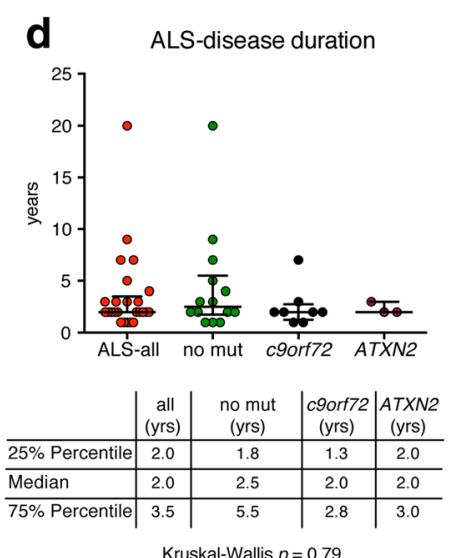

Kruskal-Wallis $p=0.79$

Fig. 1 Case demographics. a. Spinal cord tissue from 16 patients with no history of neurodegenerative disease was examined in this study; 7 were female and 9 were male. $\mathbf{b}$. The spinal cord from 27 patients diagnosed with ALS were examined in this study; 11 were female and 16 were male. c. There was no statistical difference in the age of death between the normal and ALS patients. The graph represents the median with interquartile range. A Mann-Whitney test was used to test for significance. $\mathbf{d}$. Compared to the no-mutation carriers, the presence of a mutation in C9orf72 or an intermediate polyQ expansion in ATXN2 did not cause a significant change in disease duration in these pre-selected cohorts. The graph represents the median with interquartile range. A Kruskal-Wallis test was used to test for significance 

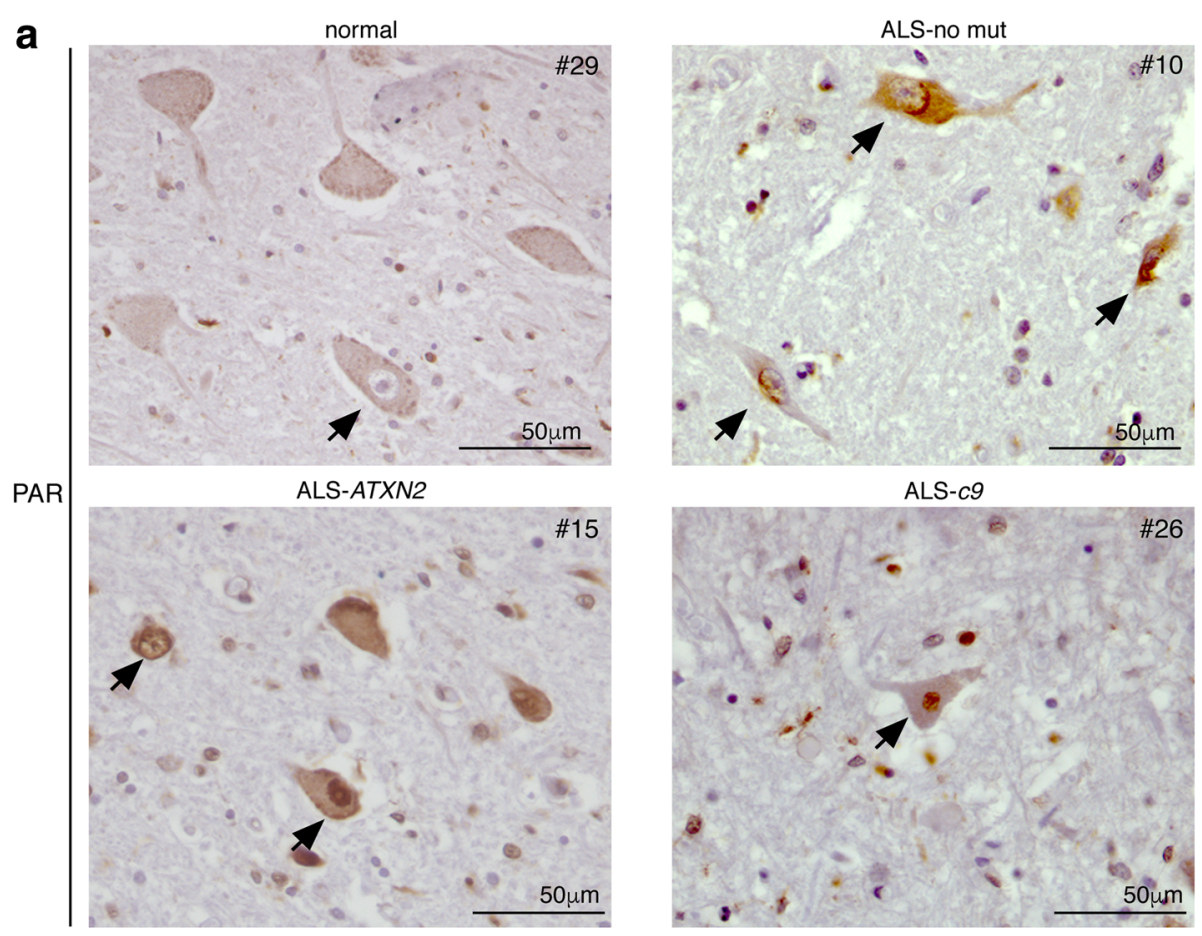

b
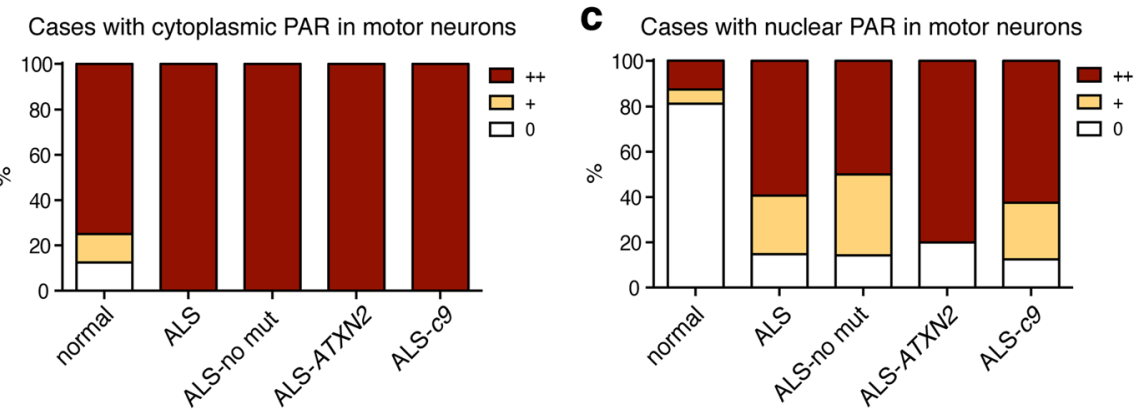

Fig. 2 ALS motor neurons have elevated levels of nuclear PAR. a. Spinal cord sections from a neurologically normal case showing a motor neuron with no nuclear PAR immunoreactivity (arrow). An ALS-no mut case with three motor neurons with nuclear PAR (arrows). An ALS-ATXN2 case with two motor neurons presenting with nuclear PAR (arrows). An ALS-c9 case with one motor neuron with nuclear PAR (arrow). Sections were immunostained for PAR and counterstained with Hematoxylin. $\mathbf{b}$. The presence of cytoplasmic PAR in the motor neurons of the spinal cord was quantified on a semi-quantitative scale ( 0 no detectable cytoplasmic PAR; + cytoplasmic PAR detected in 1 motor neuron; ++ cytoplasmic PAR detected in $>1$ motor neuron), see also Tables 3 and 4 . The data was charted as a percentage. $\mathbf{c}$. The presence of nuclear PAR in the motor neurons of the spinal cord was quantified on a semi-quantitative scale ( 0 no detectable nuclear PAR; + nuclear PAR detected in 1 motor neuron; ++ nuclear PAR detected in $>1$ motor neuron), see also Tables 3 and 4 . The data were charted as a percentage. Slides were fully blinded and examined independently by two researchers, images for figures were captured with a 20X objective and an optivar magnification of 1.6

the ALS-all anterior horn had significantly more motor neurons $(19.5 \pm 1.4$ vs $13.7 \pm 1.4(\mathrm{SEM}) p=0.0081)$ and significantly more visible nuclei $(5.6 \pm 0.6$ vs $4.0 \pm 0.4$ (SEM) $p=0.0393$ ). It is likely that the severity of nuclear PAR staining in ALS is under represented in our analyses. Combined, our data indicate that the motor neurons of the post-mortem spinal cord from ALS patients exhibit significantly elevated levels of nuclear PAR.

Motor neurons do not have cytoplasmic inclusions of PAR To gain further insight into the pattern of PAR immunoreactivity in the ALS spinal cord, we determined whether PAR formed neuronal cytoplasmic inclusions in neurons that contained phosphorylated TDP-43. Serial sections of spinal cord from 4 ALS patients were immunostained with either an antibody that selectively detects TDP-43 phosphorylated at serines 409/410 (pS409/10) or with an antibody that detects PAR. In all 4 cases (case numbers: 22, 23, 25 and 26) cytoplasmic inclusions of phosphorylated TDP-43 were present in the motor neurons (Fig. 3a). In serial sections, we found no evidence of PAR aggregation in the cytoplasm in the neurons in which phosphorylated TDP-43 was detected (Fig. 3a). Additionally, in these 4 cases $(22,23,25$ and 26) nuclear 
Table 3 PAR immunoreactivity in patients with no known neurological disease

\begin{tabular}{|c|c|c|c|c|}
\hline$\#$ & Diagnosis & $\begin{array}{l}\text { Region } \\
\text { analyzed }\end{array}$ & $\begin{array}{l}\text { PAR in } \\
\text { MN nuclei }\end{array}$ & $\begin{array}{l}\text { PAR in MN } \\
\text { cytoplasm }\end{array}$ \\
\hline 1 & normal & cervical & 0 & 0 \\
\hline 2 & normal & cervical & 0 & ++ \\
\hline 3 & normal & cervical & ++ & ++ \\
\hline 4 & normal & cervical & 0 & ++ \\
\hline 5 & normal & cervical & 0 & 0 \\
\hline 6 & normal & cervical & 0 & ++ \\
\hline 7 & normal & lumbar & + & + \\
\hline 8 & normal & cervical & 0 & + \\
\hline 9 & normal & lumbar & 0 & ++ \\
\hline 10 & normal & cervical & 0 & ++ \\
\hline 11 & normal & cervical & 0 & ++ \\
\hline 12 & normal & cervical & 0 & ++ \\
\hline 13 & normal & cervical & ++ & ++ \\
\hline 14 & normal & thoracic & 0 & ++ \\
\hline 15 & normal & cervical & 0 & ++ \\
\hline 16 & normal & cervical & 0 & ++ \\
\hline
\end{tabular}

Abbreviations: \#: case number. Normal diagnosed neurologically normal. $F$ female, M, male. PAR poly(ADP-ribose). $M N$ motor neuron

PAR was present in motor neurons, and in serial sections none of those motor neurons displayed phosphorylated TDP-43 pathology (Fig. 3b). These data indicate that nuclear PAR occurred in motor neurons that have not developed phosphorylated TDP-43 pathology.

\section{Veliparib suppresses the formation of stress-induced foci of TDP-43}

Since nuclear PAR was detected in motor neurons of the ALS spinal cord, the activity of the nuclear PARPs may be activated in disease. There are three nuclear PARP enzymes: PARP-1, PARP-2, and also PARP-3, which is a mono(ADP-ribose) transferase [41, 48, 60]. The antibody used to detect PAR recognizes PAR chains of 20 or more ADP-ribose subunits [52], suggesting that the PAR detected in the ALS spinal cord (see Figs. 2 and 3) is generated from PARP-1 or PARP-2 (collectively known as PARP-1/2). Small-molecule inhibitors of PARP-1/2 activity have been pursued as cancer therapeutics in more than 300 FDA-approved clinical trials [54, 102]. We thus sought to determine if PARP-1/2 inhibition could be of potential therapeutic value to ALS.

In cells, TDP-43 can be induced to aggregate and localize to cytoplasmic stress granules. It has been reported that the PARP-1/2 inhibitor, Veliparib, inhibits the formation cytoplasmic stress granules [23, 49]. We determined the efficacy of Veliparib to mitigate the formation of arsenite-induced TIAR-labelled stress granules in COS-7 cells (Fig. 4a). Upon exposure to $0.25 \mathrm{mM}$ sodium arsenite, the percentage of cells with TIAR-labelled stress granules increased from $6 \pm 1 \%$ to $29 \pm 2 \%$ (SEM) (Fig. 4b-c). Co-treatment with $10 \mu \mathrm{M}$ Veliparib reduced the percentage of cells with arsenite-induced TIAR-labelled stress granules to $9 \pm 1 \%$ (SEM) (Fig. 4b-c). To examine the efficacy of Veliparib to mitigate cytoplasmic aggregation of TDP-43 in COS-7 cells, we exogenously expressed TDP-43-YFP. Normally, TDP-43-YFP was diffusely nuclear, however upon exposure to $0.25 \mathrm{mM}$ sodium arsenite the percentage of cells with cytoplasmic TDP-43-YFP foci increased from $3 \pm 1 \%$ to $30 \pm 1 \%$ (SEM) (Fig. 4d-e). Co-treatment with Veliparib significantly reduced the percentage of cells with arsenite-induced TDP-43-YFP foci to near control levels $(5 \pm 1 \%$ (SEM)) (Fig. 4d-e). These data suggest that in response to arsenite exposure, PARP-1/2 activity regulates stress-granule formation and stress-induced TDP-43 aggregation in the cytoplasm.

\section{Veliparib mitigates TDP-43 toxicity in primary spinal cord neurons}

Since Veliparib inhibited the accumulation of stress-induced TDP-43 foci in the cytoplasm, we queried whether this treatment could impact the toxicity of TDP-43 to primary spinal cord cultures. To address this question, we developed a toxicity assay in mixed spinal-cord cultures isolated from rat embryos (Fig. 5a). The primary spinal cord cultures were virally infected with an attenuated herpes simplex virus expressing a LacZ control or of TDP-43. The cultures were maintained for $5 \mathrm{~d}$ post infection, after which they were immunostained for the neuronal specific marker Neurofilament-H (NF-H) and the remaining $\mathrm{NF}-\mathrm{H}$-labeled cell bodies were imaged and quantified. In control conditions (LacZ), we observed an average of $102 \pm 5.6$ (SEM) neuronal cell bodies (Fig. 5b-c). Infection with TDP-43 at $0.25 \times, 0.5 \times$ and $1 \times$ resulted in a dose-sensitive loss of neurons $(76 \pm 2.2,63 \pm 2.4$ and 38 \pm 2.4 (SEM) neuronal cell bodies respectively) (Fig. 5b-c), indicating that virally expressed TDP-43 results in neuronal cell loss in rat spinal cord cultures.

To determine if Veliparib was effective at mitigating TDP-43-associated neuronal degeneration, we first examined spinal cord cultures infected with the LacZ control and treated with either DMSO or with $1 \mu \mathrm{M}$ or $5 \mu \mathrm{M}$ Veliparib. These controls revealed that Veliparib had no deleterious effects on the mixed spinal cord cultures at the concentrations tested (Fig. 5b-c). We then compared rat spinal cord cultures infected with TDP-43 and co-treated with DMSO or $1 \mu \mathrm{M}$ or $5 \mu \mathrm{M}$ Veliparib. Notably, treatment with $5 \mu \mathrm{M}$ Veliparib protected the primary neurons such that there was no significant difference in the number of neuronal cell bodies, at all infection ratios of TDP-43 compared to the DMSO 
Table 4 PAR immunoreactivity in patients diagnosed with neurological disease

\begin{tabular}{|c|c|c|c|c|c|}
\hline$\#$ & Diagnosis & Mutation Status & Region analyzed & PAR in MN nuclei & PAR in MN cytoplasm \\
\hline 17 & ALS & - & cervical & + & ++ \\
\hline 18 & ALS & - & lumbar & ++ & ++ \\
\hline 19 & ALS & - & cervical & ++ & ++ \\
\hline 20 & ALS-D & - & lumbar & ++ & ++ \\
\hline 21 & ALS & - & lumbar & ++ & ++ \\
\hline 22 & ALS & - & lumbar & ++ & ++ \\
\hline 23 & ALS & - & lumbar & 0 & ++ \\
\hline 24 & ALS & - & cervical & + & ++ \\
\hline 25 & ALS & - & cervical & + & ++ \\
\hline 26 & ALS-D & - & cervical & ++ & ++ \\
\hline 27 & ALS/PLS & - & cervical & + & ++ \\
\hline 28 & ALS & - & cervical & 0 & ++ \\
\hline 29 & ALS & - & lumbar & ++ & ++ \\
\hline 30 & ALS & - & cervical & + & ++ \\
\hline 31 & ALS & ATXN2 (22/32) & cervical & ++ & ++ \\
\hline 32 & ALS-D & ATXN2 (22/27) & cervical & ++ & ++ \\
\hline 33 & ALS & ATXN2 (20/31) & thoracic & ++ & ++ \\
\hline 34 & ALS & ATXN2 (22/29) & lumbar & ++ & ++ \\
\hline 35 & ALS & ATXN2 (22/27) & cervical & 0 & ++ \\
\hline 36 & ALS & C9orf72 & cervical & ++ & ++ \\
\hline 37 & FTD & C9orf72 & cervical & ++ & ++ \\
\hline 38 & ALS-D & C9orf72 & cervical & ++ & ++ \\
\hline 39 & ALS-D & C9orf72 & thoracic & 0 & ++ \\
\hline 40 & ALS-D & C9orf72 & thoracic & ++ & ++ \\
\hline 41 & ALS-D & C9orf72 & cervical & + & ++ \\
\hline 42 & ALS-D & C9orf72 & lumbar & ++ & ++ \\
\hline 43 & ALS & C9orf72 & sacral & + & ++ \\
\hline
\end{tabular}

Abbreviations: \#: case number. -: No known mutation in TARDBP, UBQLN2, ATXN2, and C9orf72. ATXN2 refers to an intermediate CAG-trinucleotide expansion in ATXN2 (pathologic repeat length is indicated in brackets). C9orf72 refers to a GGGGCC-hexanucleotide repeat expansion. ALS-D ALS with dementia, FTD frontotemporal degeneration, PLS primary lateral sclerosis, PAR poly(ADP-ribose), MN motor neuron
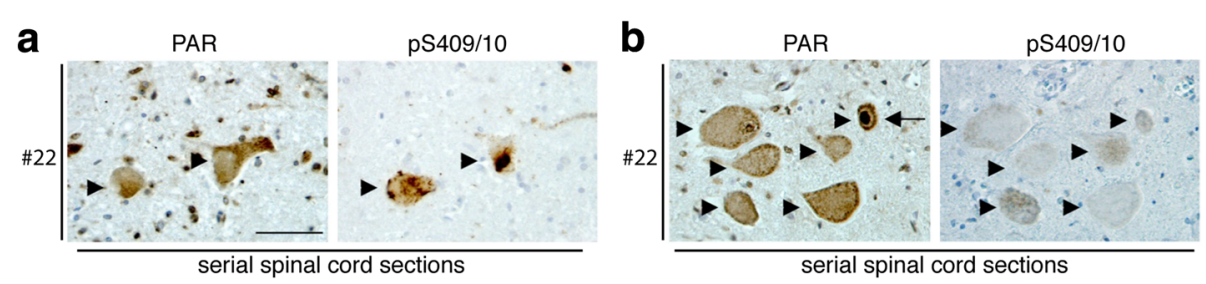

Fig. 3 PAR does not form protein aggregates in the cytoplasm of motor neurons. a. Serial sections from ALS spinal cord tissue were stained for either PAR or phosphorylated TDP-43 (pS409/10). Motor neurons with phosphorylated TDP-43 aggregates did not also have cytoplasmic aggregates labelled with PAR. Arrowheads indicate the same neurons in each serial section. Scale bar: 50 um. b. Serial sections of ALS spinal cord tissue were stained for either PAR or phosphorylated TDP-43 (pS409/10). The motor neurons shown with elevated nuclear PAR did not have cytoplasmic aggregates of phosphorylated TDP-43. Arrowheads indicate the same neuron in each section. Arrows indicate neuron with nuclear PAR. Scale bar: $50 \mu \mathrm{m}$ 

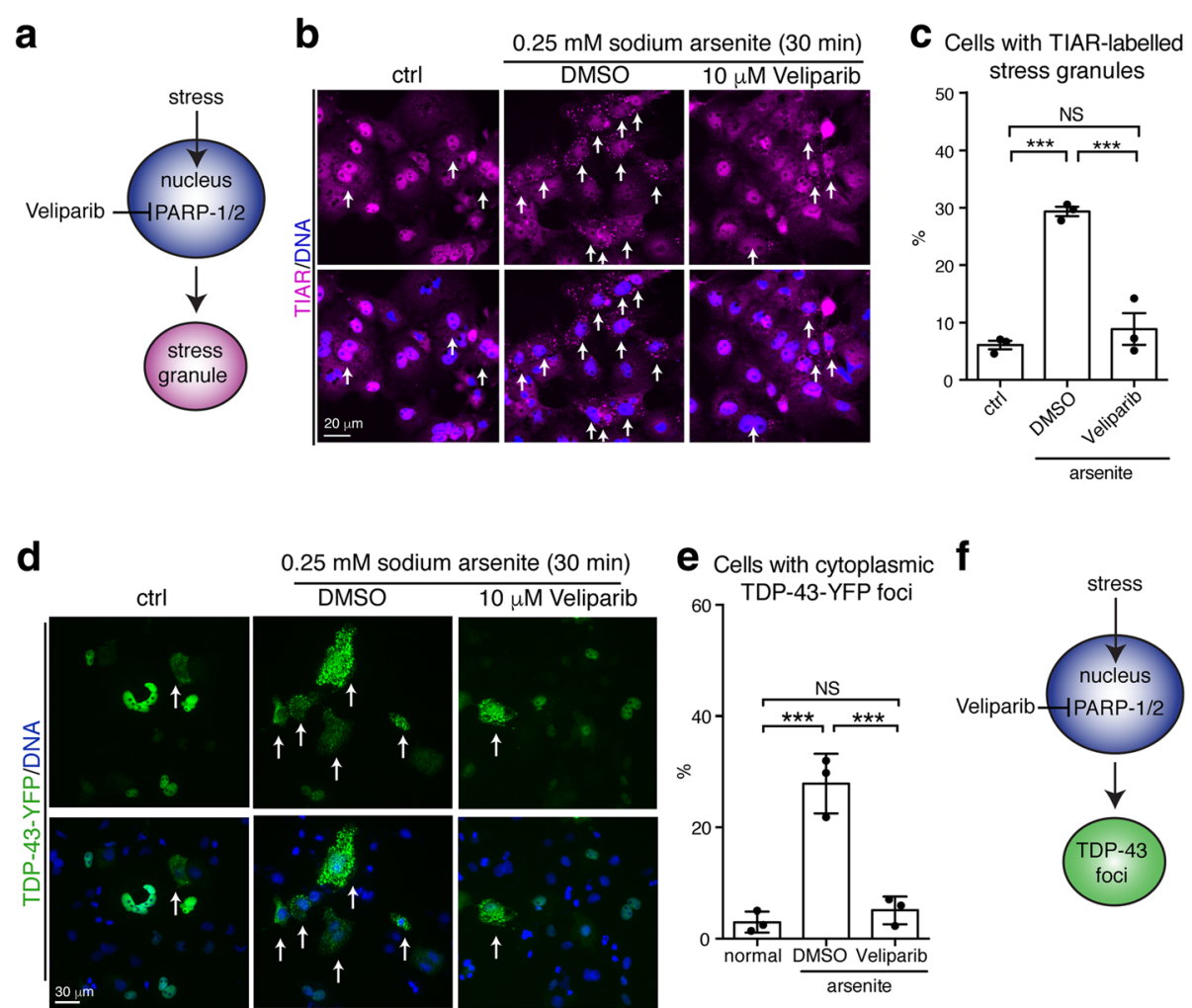

Fig. 4 Small molecule inhibition of PARP-1/2 reduces the formation of stress-induced TDP-43 foci in mammalian cells. a Veliparib is a small molecule inhibitor of PARP-1/2 activity reported to inhibit the formation of G3BP1-labelled foci in the cytoplasm upon UV treatment [49]. $\mathbf{b}$ Exposure to arsenite leads to the formation of TIAR-labelled stress granules in the cytoplasm (arrows). Co-treatment with Veliparib inhibits the formation of TIAR-labelled stress granules. COS-7 cells transfected with TDP-43-YFP were immunostained for TIAR and counterstained with Hoescht. Cells were imaged for TIAR and Hoescht. c Cells were quantified for the presence of cytoplasmic TIAR-labelled stress granules. Mean ( \pm SEM) is presented. One-way ANOVA followed by a Tukey's test was used for significance. $\mathbf{d}$ Under normal conditions (ctrl), TDP-43-YFP diffusely localizes to the nucleus of COS-7 cells. Upon treatment with arsenite, TDP-43-YFP forms foci in the cytoplasm (arrows). The formation of cytoplasmic TDP-43-YFP foci is inhibited by treatment with Veliparib. Cells were counterstained with Hoescht. e Veliparib reduces the accumulation of TDP-43-YFP foci in the cytoplasm. Cells were quantified for the presence of cytoplasmic TDP-43-YFP foci. Mean ( \pm SEM) is presented. One-way ANOVA $(p=0.0002)$ followed by a Tukey's test was used for significance. $\mathbf{f}$ Hypothetical schematic showing that inhibition of PARP-1/2 activation by Veliparib inhibits the formation of stress-induced TDP-43-YFP foci

control (Fig. 5b-c). The neuronal processes appeared retained although not to the level of the control (Fig. 5c). These studies cannot determine whether the neurons or astrocytes account for TDP-43-associated neuronal loss or for the beneficial action of Veliparib. However, small molecule inhibition of PARP-1/2 is effective in mitigating TDP-43-associated neuronal loss in these spinal cord cultures, and could have therapeutic utility for ALS and other TDP-43-associated diseases.

\section{Discussion}

Our data indicate that ALS is associated with elevated nuclear PAR in the motor neurons of the spinal cord in all genetic backgrounds tested (no mutation, intermediate polyQ expansion in ATXN2 or C9orf72 mutation). We show that Veliparib, an inhibitor of nuclear PARP-1/ 2 activity, mitigates the formation of stress-induced cytoplasmic aggregates of TDP-43 in mammalian cells. We extend this finding to show that treating rodent spinal-cord cultures with Veliparib mitigates TDP-43-induced neuronal cell loss. Collectively, our data implicate the misregulation of nuclear PARP activity in ALS and highlight PARP-1/2 inhibitors as potential compounds for further therapeutic research.

In the early stages of ALS some patients will present with symptoms of neuronal hyperexcitability such as fasciculation and cramp $[7,111]$. In support of hyperexcitability as a physiological mechanism, glutamate, the major excitatory neurotransmitter in the CNS, is elevated in the cerebrospinal fluid of ALS patients [93, 94, 101, 103]. Notably, PARP-1 activation has been implicated in meditating the response to glutamate-induced neurotoxicity in animal and cellular assays [5, 24, 113, 116]. Our neuropathologic analyses demonstrate that long-chained PAR polymers are present at elevated levels in the motor-neuron nuclei of the ALS spinal cord. This 


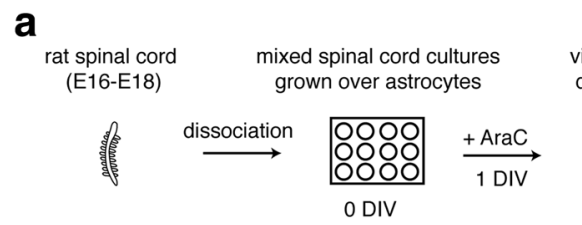

b

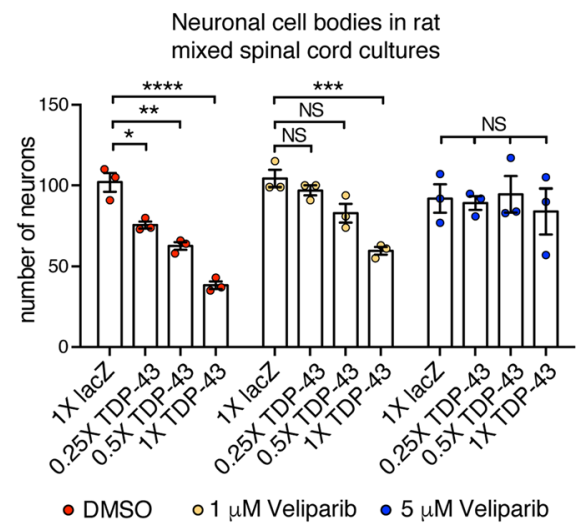

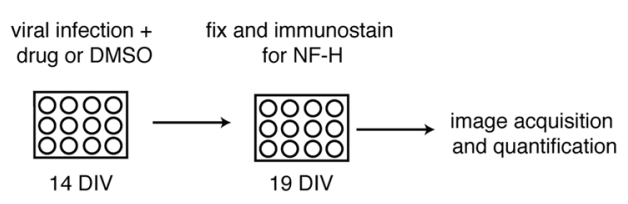

C

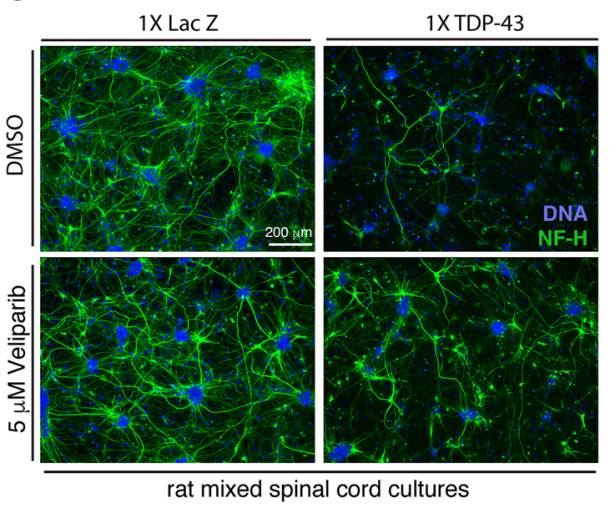

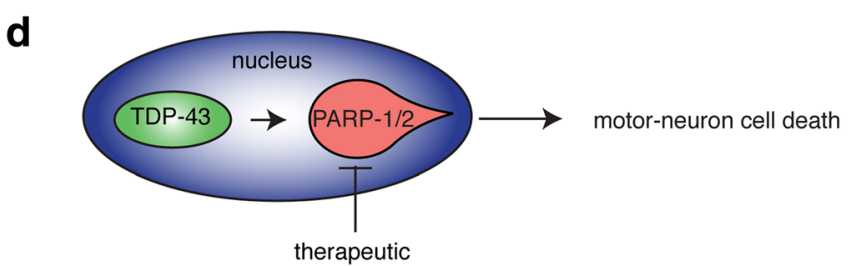

Fig. 5 Veliparib inhibits TDP-43-associated neuronal loss in rat spinal cord cultures. a. The spinal cord was isolated from Sprague Dawley embryos (E16-E18), dissociated with protease and DNase, and seeded onto astrocyte coated 12-well plates. After 1 day in vitro (1 DIV) cell proliferation was stopped by the addition of $5 \mu \mathrm{M}$ cytosine arabinoside (AraC). At 14 DIV cultures were infected with a LacZ control or TDP-43 attenuated herpes simplex virus alongside DMSO or Veliparib. At 19 DIV the neurons were fixed and immunostained for the neuronal marker neurofilament-H (NF-H) and counterstained with Hoescht. Five images (10X magnification) were captured from each condition and neuronal cell bodies were counted. Each condition was repeated three times from 3 independent cultures. b. Viral infection of TDP-43 leads to the loss of neuronal cell bodies in dose-dependent manner. Co-treatment with $1 \mu \mathrm{M}$ or $5 \mu \mathrm{M}$ Veliparib inhibits TDP-43-induced neuronal cell loss. Mean $( \pm$ SEM) is presented, each data point represents three technical repeats from an independent culture. $1 \mathrm{X}$ represents a virus titer of 3-5 $\times 10^{4} \mathrm{pfu} / \mathrm{ml}$. Two-way ANOVA $(p<0.0001)$ and a Dunnett's test for significance was performed. NS: not significant. c. Example images (magnification 10X), of rat spinal-cord cultures infected with 1X LacZ or 1X TDP-43 and incubated with DMSO or $5 \mu \mathrm{M}$ Veliparib. Cultures were immunolabeled for Neuro filament-H (NF-H) and counterstained with Hoescht. $\mathbf{d}$. Schematic showing that motor neuron loss induced by virally expressed TDP-43 in spinal cord cultures and that this loss is suppressed by the PARP-1/2 inhibitor Veliparib

finding implicates activation of the nuclear PARP enzymes (PARP-1 and PARP-2). PARP-1 is the most abundant and the most active following stress [27, 67]. The downstream consequence of PARP-1 activation leads to the propagation of several stress-associated pathways [1, $21,34,63]$. Upon over activation of PARP-1, the enzyme elicits a cell death mechanism, which is characterized by cleavage of PARP-1 [34, 50, 100]. Previous reports indicate that PARP-1 protein and cleaved PARP-1 is elevated in ALS $[32,56,57]$. Combined with our data that demonstrate that PAR is elevated in ALS motor neurons it could be that PARP-1/2 is activated by localized glutamate excitotoxicity and that the motor neurons may be undergoing PAR-mediated cell death.
PARP-1/2 also plays a role in nuclear and cytoplasmic protein localization. For example, upon inflammatory stress, PARP-1/2 promotes nuclear retention of the transcription factor High mobility group B1 (HMGBP1) [1]. Under extreme conditions of DNA damage PAR polymers produced by PARP-1 are released into the cytoplasm and bind to Apoptosis Inducing Factor (AIF) in the mitochondria to promote translocation of AIF and macrophage migration inhibitory factor (MIF) to the nucleus to elicit a programmed cell death mechanism [34, 113, 114]. PARP-1 activity has also been implicated in signaling to PARP-12 in the cytoplasm to regulate the formation of cytoplasmic stress granules [23, 49]. Here we show that treatment with PARP-1/2 inhibitor, Veliparib, mitigates 
the formation of stress-induced aggregates of TDP-43 in the cytoplasm, suggesting that PARP-1/2 activity impacts cytoplasmic aggregation of TDP-43. Indeed, nuclear PAR was not detected in neurons harboring phosphorylated TDP-43 aggregates, suggesting that the PARP- $1 / 2$ activation observed in ALS motor neurons may occur at earlier stages in neuron compromise. We suggest that PARP-1/2 activation may precede the exit of TDP-43 from the nucleus and the subsequent formation of cytoplasmic TDP-43 aggregates.

Of the $\sim 5 \%$ of ALS cases that lack TDP-43 pathology (TDP-43-negative ALS), a subset is the result of a mutation in FUS (fused in sarcoma) [46, 61, 112]. FUS is an RNA-binding protein that is recruited to sites of DNA damage by PARP- $1[3,81,96]$ and at high concentrations, the PARP-1/2 inhibitor Veliparib can promote the mislocalization of nuclear FUS-GFP to the cytoplasm [81]. A second notable gene mutated in TDP-43-negative ALS is SOD1 (superoxide dismutase 1) [69]. Curiously, PARP-1 protein is elevated in spinal cord astrocytes in SOD1 G93A transgenic mice [22] and is cleaved in SOD-1 cellular models [59]. However, pharmacological treatment with a PARP-1 inhibitor had no effect on the lifespan or motor performance of the SOD1 G93A transgenic mouse [6]. It is possible that PARP-1/2 regulation of neuronal demise is selectively involved in TDP-43-positive ALS. In support of PARP-1 mediated regulation of the central nervous system in disease it has been shown that PARP-1 overactivation leads to neuronal degeneration in Drosophila [43]. PARP-1 activation has also been linked to Alzheimer's (AD), Parkinson's (PD) and ischemic stroke [19, $31,51,71,72,79]$, and the use of PARP-1/2 inhibitors is beneficial to mouse models of these diseases [2, 20, $25,30,87,105,109,115]$. These data indicate that, despite dampening the DNA damage response, PARP-1/2 inhibition provides improved neuronal integrity and function in these animal models of disease. To assign therapeutic potential of PARP-1/2 inhibitors and understand potential side effects, it will be imperative to examine additional ALS subtypes and associated diseases.

A range of small-molecule inhibitors of PARP-1/2, including the inhibitor used here, have been developed for clinical application as they sensitize cancer cells to cell death. Moreover, some have been reported to cross the blood-brain barrier [16, 17, 33]. These inhibitors have been tested in hundreds of FDA-approved clinical trials of various cancers and there is a wealth of information on the pharmacokinetics, pharmacodynamics, and toxicity of these compounds that would be beneficial in repurposing them for alternative diseases $[11,54,102]$. We previously implicated inhibitors of PARP-5a and PARP-5b, collectively known as PARP-5a/5b, in reducing the cytoplasmic aggregation of TDP-43, without having an effect on the percentage of cells with G3BP1-positive stress granules [73]. PARP-5a/5b inhibitors are also in development as cancer therapeutics $[42,62,70]$. It is possible that PARP-1/2 more broadly effects stress granule formation and stress-induced protein aggregation, while PARP-5a/5b may act on select proteins in stress signaling.

\section{Conclusion}

Our study implicates the activation of PARP- $1 / 2$ in the motor neuron nuclei of the ALS spinal cord. We show that treatment with Veliparib, a PARP-1/2 inhibitor, reduces stress-induced accumulation of TDP-43 in the cytoplasm of mammalian cells. Furthermore, we show that Veliparib can mitigate the toxic effect of virally expressed TDP-43 in rodent spinal cord cultures. Currently, the mechanisms that may link TDP-43 and PARP-1/2 in cell culture models and human disease remains to be elucidated. We suggest that the PARP superfamily is an area that should be explored further in ALS therapeutics.

\section{Funding}

This work was funded by grants from the Life Extension Foundation (JS), ALS Association (JS), Department of Biochemistry and Biophysics Pilot Grant (JS), Target ALS (JS and NMB), the Glenn Foundation (NMB), the Robert Packard Center for ALS Research at Johns Hopkins (JS), AG-017586 (WD), and the NIH: R01 NS095746-01 (RGK), R21NS093439 (RGK), 5R21NS087077-02 (RGK), R01GM099836 (JS), R21NS090205 (JS), P30AG10124 (VMYL and JQT), P01AG17586 (VMYL and JQT), R01NS095793 (EBL) 5R01NS073660 (NMB), R35NS097275 (NMB).

\section{Availability of data and materials}

All raw data presented are available upon reasonable request.

\section{Authors' contributions}

LM conceived, designed and performed experiments, performed statistical analysis and analyzed data. EBL analyzed data. VMVD, VML, JM-P, RGK and JQT contributed reagents and materials. JS contributed intellectual input, RGK, EBL and NMB conceived and designed experiments, analyzed data and supervised the research. LM and NMB wrote the manuscript. All authors read and approved the final manuscript.

\section{Ethics approval and consent to participate}

Informed consent was obtained from next of kin in accordance with institutional review board guidelines of the University of Pennsylvania.

\section{Consent for publication}

All authors consent to publication.

\section{Competing interests}

The authors declare that they have no competing interests.

\section{Publisher's Note}

Springer Nature remains neutral with regard to jurisdictional claims in published maps and institutional affiliations.

\footnotetext{
Author details

'Department of Biology, University of Pennsylvania, Philadelphia, PA 19104, USA. ${ }^{2}$ Department of Neurology, Children's Hospital of Philadelphia, Joseph Stokes Jr. Research Institute, Philadelphia, PA 19104, USA. ${ }^{3}$ Present address: Les Turner ALS Center at Northwestern Medicine, Feinberg School of Medicine, Northwestern University, Chicago, IL 60611, USA. ${ }^{4}$ Department of Pathology and Laboratory Medicine, Perelman School of Medicine, Philadelphia, PA 19104, USA. ${ }^{5}$ Department of Biochemistry and Biophysics, Perelman School of Medicine at the University of Pennsylvania, Philadelphia, PA 19104, USA. ${ }^{6}$ Translational Neuropathology Research Laboratory, 605B Stellar Chance Laboratories, 422 Curie Blvd, Philadelphia, PA 19104, USA.
} 
Received: 16 July 2018 Accepted: 19 August 2018 Published online: 29 August 2018

\section{References}

1. Abd Elmageed ZY, Naura AS, Errami Y, Zerfaoui M (2012) The poly(ADPribose) polymerases (PARPs): new roles in intracellular transport. Cell Signal 24:1-8. https://doi.org/10.1016/j.cellsig.2011.07.019

2. Abdelkarim GE, Gertz K, Harms C, Katchanov J, Dirnagl U, Szabo C, Endres M (2001) Protective effects of PJ34, a novel, potent inhibitor of poly(ADPribose) polymerase (PARP) in in vitro and in vivo models of stroke. Int J Mol Med 7:255-260

3. Altmeyer M, Neelsen K, Teloni F, Pozdnyakova I, Pellegrino S, Grofte M, Rask MB, Streicher W, Jungmichel S, Nielsen ML et al (2015) Liquid demixing of intrinsically disordered proteins is seeded by poly(ADP-ribose). Nat Commun 6:8088. https://doi.org/10.1038/ncomms9088

4. Anderson P, Kedersha N (2008) Stress granules: the Tao of RNA triage. Trends Biochem Sci 33:141-150. https://doi.org/10.1016/j.tibs.2007.12.003

5. Andrabi SA, Kang HC, Haince JF, Lee Yl, Zhang J, Chi Z, West AB, Koehler RC, Poirier GG, Dawson TM et al (2011) Iduna protects the brain from glutamate excitotoxicity and stroke by interfering with poly(ADP-ribose) polymer-induced cell death. Nat Med 17:692-699. https://doi.org/10.1038/ nm.2387

6. Andreassen OA, Dedeoglu A, Friedlich A, Ferrante KL, Hughes D, Szabo C, Beal MF (2001) Effects of an inhibitor of poly(ADP-ribose) polymerase, desmethylselegiline, trientine, and lipoic acid in transgenic ALS mice. Exp Neurol 168:419-424. https://doi.org/10.1006/exnr.2001.7633

7. Bae JS, Simon NG, Menon P, Vucic S, Kiernan MC (2013) The puzzling case of hyperexcitability in amyotrophic lateral sclerosis. J Clin Neurol 9:65-74. https://doi.org/10.3988/jcn.2013.9.2.65

8. Becker LA, Huang B, Bieri G, Ma R, Knowles DA, Jafar-Nejad P, Messing J, Kim HJ, Soriano A, Auburger $G$ et al (2017) Therapeutic reduction of ataxin-2 extends lifespan and reduces pathology in TDP-43 mice. Nature 544:367371. https://doi.org/10.1038/nature22038

9. Benkler C, Offen D, Melamed E, Kupershmidt L, Amit T, Mandel S, Youdim MB, Weinreb O (2010) Recent advances in amyotrophic lateral sclerosis research: perspectives for personalized clinical application. EPMA J 1:343361. https://doi.org/10.1007/s13167-010-0026-1

10. Bentmann E, Neumann M, Tahirovic S, Rodde R, Dormann D, Haass C (2012) Requirements for stress granule recruitment of fused in sarcoma (FUS) and TAR DNA-binding protein of 43 kDa (TDP-43). J Biol Chem 287:2307923094. https://doi.org/10.1074/jbc.M111.328757

11. Berger NA, Besson VC, Boulares AH, Burkle A, Chiarugi A, Clark RS, Curtin NJ, Cuzzocrea S, Dawson TM, Dawson VL et al (2018) Opportunities for the repurposing of PARP inhibitors for the therapy of non-oncological diseases. Br J Pharmacol 175:192-222. https://doi.org/10.1111/bph.13748

12. Braak H, Alafuzoff I, Arzberger T, Kretzschmar H, Del Tredici K (2006) Staging of Alzheimer disease-associated neurofibrillary pathology using paraffin sections and immunocytochemistry. Acta Neuropathol 112:389-404. https:// doi.org/10.1007/s00401-006-0127-z

13. Braak H, Braak E (1991) Neuropathological stageing of Alzheimer-related changes. Acta Neuropathol 82:239-259

14. Brettschneider J, Arai K, Del Tredici K, Toledo JB, Robinson JL, Lee EB, Kuwabara S, Shibuya K, Irwin DJ, Fang L et al (2014) TDP-43 pathology and neuronal loss in amyotrophic lateral sclerosis spinal cord. Acta Neuropathol 128:423-437. https://doi.org/10.1007/s00401-014-1299-6

15. Brettschneider J, Del Tredici K, Toledo JB, Robinson JL, Irwin DJ, Grossman M, Suh E, Van Deerlin VM, Wood EM, Baek Y et al (2013) Stages of pTDP-43 pathology in amyotrophic lateral sclerosis. Ann Neurol 74: 20-38 Doi https://doi.org/10.1002/ana.23937

16. Bryant HE, Schultz N, Thomas HD, Parker KM, Flower D, Lopez E, Kyle S, Meuth M, Curtin NJ, Helleday T (2005) Specific killing of BRCA2-deficient tumours with inhibitors of poly(ADP-ribose) polymerase. Nature 434:913917. https://doi.org/10.1038/nature03443

17. Calabrese CR, Almassy R, Barton S, Batey MA, Calvert AH, Canan-Koch S, Durkacz BW, Hostomsky Z, Kumpf RA, Kyle S et al (2004) Anticancer chemosensitization and radiosensitization by the novel poly(ADP-ribose) polymerase-1 inhibitor AG14361. J Natl Cancer Inst 96:56-67

18. Caldecott KW (2014) Protein ADP-ribosylation and the cellular response to DNA strand breaks. DNA Repair (Amst) 19:108-113. https://doi.org/10.1016/j. dnarep.2014.03.021
19. Chiarugi A (2005) Poly(ADP-ribosyl)ation and stroke. Pharmacol Res 52:1524. https://doi.org/10.1016/j.phrs.2005.02.018

20. Chiarugi A, Meli E, Calvani M, Picca R, Baronti R, Camaioni E, Costantino G, Marinozzi M, Pellegrini-Giampietro DE, Pellicciari R et al (2003) Novel isoquinolinone-derived inhibitors of poly(ADP-ribose) polymerase-1: pharmacological characterization and neuroprotective effects in an in vitro model of cerebral ischemia. J Pharmacol Exp Ther 305:943-949. https://doi. org/10.1124/jpet.103.048934

21. Chung HT, Joe Y (2014) Antagonistic crosstalk between SIRT1, PARP-1, and -2 in the regulation of chronic inflammation associated with aging and metabolic diseases. Integr Med Res 3:198-203. https://doi.org/10.1016/j.imr.2014.09.005

22. Chung YH, Joo KM, Lee YJ, Shin DH, Cha Cl (2004) Reactive astrocytes express PARP in the central nervous system of SOD(G93A) transgenic mice. Brain Res 1003:199-204. https://doi.org/10.1016/j.brainres.2004.01.010

23. Citarelli M, Teotia S, Lamb RS (2010) Evolutionary history of the poly(ADPribose) polymerase gene family in eukaryotes. BMC Evol Biol 10:308. https:// doi.org/10.1186/1471-2148-10-308

24. Cosi C, Suzuki H, Milani D, Facci L, Menegazzi M, Vantini G, Kanai Y, Skaper SD (1994) Poly(ADP-ribose) polymerase: early involvement in glutamateinduced neurotoxicity in cultured cerebellar granule cells. J Neurosci Res 39: 38-46. https://doi.org/10.1002/jnr.490390106

25. Culmsee C, Zhu C, Landshamer S, Becattini B, Wagner E, Pellecchia M, Blomgren K, Plesnila N (2005) Apoptosis-inducing factor triggered by poly(ADP-ribose) polymerase and bid mediates neuronal cell death after oxygen-glucose deprivation and focal cerebral ischemia. J Neurosci 25: 10262-10272. https://doi.org/10.1523/JNEUROSCI.2818-05.2005

26. Dash RP, Babu RJ, Srinivas NR (2018) Two decades-long journey from Riluzole to Edaravone: revisiting the clinical pharmacokinetics of the only two amyotrophic lateral sclerosis therapeutics. Clin Pharmacokinet. https:// doi.org/10.1007/s40262-018-0655-4

27. Dawson VL, Dawson TM (2004) Deadly conversations: nuclear-mitochondrial cross-talk. J Bioenerg Biomembr 36:287-294. https://doi.org/10.1023/B:JOBB. 0000041755.22613.8d

28. DeJesus-Hernandez M, Mackenzie IR, Boeve BF, Boxer AL, Baker M, Rutherford NJ, Nicholson AM, Finch NA, Flynn H, Adamson J et al (2011) Expanded GGGGCC hexanucleotide repeat in noncoding region of C9ORF72 causes chromosome 9p-linked FTD and ALS. Neuron 72:245-256. https://doi.org/10.1016/j.neuron.2011.09.011

29. Elden AC, Kim HJ, Hart MP, Chen-Plotkin AS, Johnson BS, Fang X, Armakola M, Geser F, Greene R, Lu MM et al (2010) Ataxin-2 intermediate-length polyglutamine expansions are associated with increased risk for ALS. Nature 466:1069-1075. https://doi.org/10.1038/nature09320

30. Endres M, Scott GS, Salzman AL, Kun E, Moskowitz MA, Szabo C (1998) Protective effects of 5-iodo-6-amino-1,2-benzopyrone, an inhibitor of poly(ADP-ribose) synthetase against peroxynitrite-induced glial damage and stroke development. Eur J Pharmacol 351:377-382

31. Endres M, Wang ZQ, Namura S, Waeber C, Moskowitz MA (1997) Ischemic brain injury is mediated by the activation of poly(ADP-ribose)polymerase. J Cereb Blood Flow Metab 17:1143-1151. https://doi.org/10.1097/00004647199711000-00002

32. Farg MA, Konopka A, Soo KY, Ito D, Atkin JD (2017) The DNA damage response (DDR) is induced by the C9orf72 repeat expansion in amyotrophic lateral sclerosis. Hum Mol Genet 26:2882-2896. https://doi.org/10.1093/ $\mathrm{hmg} / \mathrm{dd} \times 170$

33. Farmer H, McCabe N, Lord CJ, Tutt AN, Johnson DA, Richardson TB, Santarosa M, Dillon KJ, Hickson I, Knights C et al (2005) Targeting the DNA repair defect in BRCA mutant cells as a therapeutic strategy. Nature 434: 917-921. https://doi.org/10.1038/nature03445

34. Fatokun AA, Dawson VL, Dawson TM (2014) Parthanatos: mitochondriallinked mechanisms and therapeutic opportunities. Br J Pharmacol 171:2000 2016. https://doi.org/10.1111/bph.12416

35. Finelli MJ, Liu KX, Wu Y, Oliver PL, Davies KE (2015) Oxr1 improves pathogenic cellular features of ALS-associated FUS and TDP-43 mutations. Hum Mol Genet 24:3529-3544. https://doi.org/10.1093/hmg/ddv104

36. Geser F, Martinez-Lage M, Robinson J, Uryu K, Neumann M, Brandmeir NJ, Xie SX, Kwong LK, Elman L, McCluskey L et al (2009) Clinical and pathological continuum of multisystem TDP-43 proteinopathies. Arch Neurol 66:180-189. https://doi.org/10.1001/archneurol.2008.558

37. Gibson BA, Kraus WL (2012) New insights into the molecular and cellular functions of poly(ADP-ribose) and PARPs. Nat Rev Mol Cell Biol 13:411-424. https://doi.org/10.1038/nrm3376 
38. Gibson SB, Bromberg MB (2012) Amyotrophic lateral sclerosis: drug therapy from the bench to the bedside. Semin Neurol 32:173-178. https://doi.org/ 10.1055/s-0032-1329193

39. Group AS (2017) Open-label 24-week extension study of edaravone (MCl186) in amyotrophic lateral sclerosis. Amyotroph Lateral Scler Frontotemporal Degener 18:55-63. https://doi.org/10.1080/21678421.2017. 1364269

40. Group AS (2017) Safety and efficacy of edaravone in well defined patients with amyotrophic lateral sclerosis: a randomised, double-blind, placebocontrolled trial. Lancet Neurol 16:505-512. https://doi.org/10.1016/S14744422(17)30115-1

41. Gupte R, Liu Z, Kraus WL (2017) PARPs and ADP-ribosylation: recent advances linking molecular functions to biological outcomes. Genes Dev 31: 101-126. https://doi.org/10.1101/gad.291518.116

42. Haikarainen T, Krauss S, Lehtio L (2014) Tankyrases: structure, function and therapeutic implications in cancer. Curr Pharm Des 20:6472-6488

43. Hanai S, Kanai M, Ohashi S, Okamoto K, Yamada M, Takahashi H, Miwa M (2004) Loss of poly(ADP-ribose) glycohydrolase causes progressive neurodegeneration in Drosophila melanogaster. Proc Natl Acad Sci U S A 101:82-86. https://doi.org/10.1073/pnas.2237114100

44. Hardiman O, Al-Chalabi A, Chio A, Corr EM, Logroscino G, Robberecht W, Shaw PJ, Simmons Z, van den Berg LH (2017) Amyotrophic lateral sclerosis. Nat Rev Dis Primers 3:17085. https://doi.org/10.1038/nrdp.2017.85

45. Hasegawa M, Arai T, Nonaka T, Kametani F, Yoshida M, Hashizume Y, Beach TG, Buratti E, Baralle F, Morita M et al (2008) Phosphorylated TDP-43 in frontotemporal lobar degeneration and Amyotroph Lateral Scler. Ann Neurol 64:60-70. https://doi.org/10.1002/ana.21425

46. Hewitt C, Kirby J, Highley JR, Hartley JA, Hibberd R, Hollinger HC, Williams TL, Ince PG, McDermott CJ, Shaw PJ (2010) Novel FUS/TLS mutations and pathology in familial and sporadic amyotrophic lateral sclerosis. Arch Neurol 67:455-461. https://doi.org/10.1001/archneurol.2010.52

47. Hobson EV, McDermott CJ (2016) Supportive and symptomatic management of amyotrophic lateral sclerosis. Nat Rev Neurol 12:526-538. https://doi.org/10.1038/nrneurol.2016.111

48. Hottiger MO (2015) Nuclear ADP-Ribosylation and its role in chromatin plasticity, cell differentiation, and Epigenetics. Annu Rev Biochem 84:227263. https://doi.org/10.1146/annurev-biochem-060614-034506

49. Isabelle M, Gagne JP, Gallouzi IE, Poirier GG (2012) Quantitative proteomics and dynamic imaging reveal that G3BP-mediated stress granule assembly is poly(ADP-ribose)-dependent following exposure to MNNG-induced DNA alkylation. J Cell Sci 125:4555-4566. https://doi.org/10.1242/jcs.106963

50. Kaufmann SH, Desnoyers S, Ottaviano Y, Davidson NE, Poirier GG (1993) Specific proteolytic cleavage of poly(ADP-ribose) polymerase: an early marker of chemotherapy-induced apoptosis. Cancer Res 53:3976-3985

51. Kauppinen TM, Suh SW, Higashi Y, Berman AE, Escartin C, Won SJ, Wang C, Cho SH, Gan L, Swanson RA (2011) Poly(ADP-ribose)polymerase-1 modulates microglial responses to amyloid beta. J Neuroinflammation 8 : 152. https://doi.org/10.1186/1742-2094-8-152

52. Kawamitsu H, Hoshino H, Okada H, Miwa M, Momoi H, Sugimura T (1984) Monoclonal antibodies to poly(adenosine diphosphate ribose) recognize different structures. Biochemistry 23:3771-3777

53. Kedersha NL, Gupta M, Li W, Miller I, Anderson P (1999) RNA-binding proteins TIA-1 and TIAR link the phosphorylation of elF-2 alpha to the assembly of mammalian stress granules. J Cell Biol 147:1431-1442

54. Kim G, Ison G, McKee AE, Zhang H, Tang S, Gwise T, Sridhara R, Lee E, Tzou A, Philip R et al (2015) FDA approval summary: Olaparib monotherapy in patients with deleterious germline BRCA-mutated advanced ovarian Cancer treated with three or more lines of chemotherapy. Clin Cancer res 21:42574261. https://doi.org/10.1158/1078-0432.CCR-15-0887

55. Kim HJ, Raphael AR, LaDow ES, McGurk L, Weber RA, Trojanowski JQ, Lee VM, Finkbeiner S, Gitler AD, Bonini NM (2014) Therapeutic modulation of elF2alpha phosphorylation rescues TDP-43 toxicity in amyotrophic lateral sclerosis disease models. Nat Genet 46:152-160. https://doi.org/10.1038/ng 2853

56. Kim SH, Engelhardt J, Henkel JS, Siklos L, Soos J, Goodman C, Appel SH (2004) Widespread increased expression of the DNA repair enzyme PARP in brain in ALS. Neurology 62:319-322

57. Kim SH, Henkel JS, Beers DR, Sengun IS, Simpson EP, Goodman JC, Engelhardt JI, Siklos L, Appel SH (2003) PARP expression is increased in astrocytes but decreased in motor neurons in the spinal cord of sporadic ALS patients. J Neuropathol Exp Neurol 62:88-103
58. Kiskinis E, Sandoe J, Williams LA, Boulting GL, Moccia R, Wainger BJ, Han S, Peng T, Thams S, Mikkilineni S et al (2014) Pathways disrupted in human ALS motor neurons identified through genetic correction of mutant SOD1. Cell Stem Cell 14:781-795. https://doi.org/10.1016/j.stem.2014.03.004

59. Koh SH, Lee YB, Kim KS, Kim HJ, Kim M, Lee YJ, Kim J, Lee KW, Kim SH (2005) Role of GSK-3beta activity in motor neuronal cell death induced by G93A or A4V mutant hSOD1 gene. Eur J Neurosci 22:301-309. https://doi. org/10.1111/j.1460-9568.2005.04191.x

60. Krishnakumar R, Kraus WL (2010) The PARP side of the nucleus: molecular actions, physiological outcomes, and clinical targets. Mol Cell 39:8-24. https://doi.org/10.1016/j.molcel.2010.06.017

61. Kwiatkowski TJ Jr, Bosco DA, Leclerc AL, Tamrazian E, Vanderburg CR, Russ C, Davis A, Gilchrist J, Kasarskis EJ, Munsat T et al (2009) Mutations in the FUS/TLS gene on chromosome 16 cause familial amyotrophic lateral sclerosis. Science 323:1205-1208. https://doi.org/10.1126/science.1166066

62. Lehtio L, Chi NW, Krauss S (2013) Tankyrases as drug targets. FEBS J 280: 3576-3593. https://doi.org/10.1111/febs.12320

63. Leung AK (2014) Poly(ADP-ribose): an organizer of cellular architecture. J Cell Biol 205:613-619. https://doi.org/10.1083/jcb.201402114

64. Li YR, King OD, Shorter J, Gitler AD (2013) Stress granules as crucibles of ALS pathogenesis. J Cell Biol 201:361-372. https://doi.org/10.1083/jcb.201302044

65. Ling SC, Polymenidou M, Cleveland DW (2013) Converging mechanisms in ALS and FTD: disrupted RNA and protein homeostasis. Neuron 79:416-438. https://doi.org/10.1016/j.neuron.2013.07.033

66. Liu-Yesucevitz L, Bilgutay A, Zhang YJ, Vanderweyde T, Citro A, Mehta T, Zaarur N, McKee A, Bowser R, Sherman M et al (2010) Tar DNA binding protein-43 (TDP-43) associates with stress granules: analysis of cultured cells and pathological brain tissue. PLoS One 5:e13250. https://doi.org/10.1371/ journal.pone.0013250

67. Luo X, Kraus WL (2012) On PAR with PARP: cellular stress signaling through poly(ADP-ribose) and PARP-1. Genes Dev 26:417-432. https://doi.org/10. 1101/gad.183509.111

68. Luscher B, Butepage M, Eckei L, Krieg S, Verheugd P, Shilton BH (2018) ADPRibosylation, a multifaceted posttranslational modification involved in the control of cell physiology in health and disease. Chem Rev 118:1092-1136. https://doi.org/10.1021/acs.chemrev.7b00122

69. Mackenzie IR, Bigio EH, Ince PG, Geser F, Neumann M, Cairns NJ, Kwong LK, Forman MS, Ravits J, Stewart H et al (2007) Pathological TDP-43 distinguishes sporadic amyotrophic lateral sclerosis from amyotrophic latera sclerosis with SOD1 mutations. Ann Neurol 61:427-434. https://doi.org/10. 1002/ana.21147

70. Mariotti L, Pollock K, Guettler S (2017) Regulation of Wnt/beta-catenin signalling by tankyrase-dependent poly(ADP-ribosyl)ation and scaffolding. $\mathrm{Br}$ J Pharmacol 174:4611-4636. https://doi.org/10.1111/bph.14038

71. Martire S, Fuso A, Rotili D, Tempera I, Giordano C, De Zottis I, Muzi A, Vernole P, Graziani G, Lococo E et al (2013) PARP-1 modulates amyloid beta peptide-induced neuronal damage. PLoS One 8:e72169. https://doi.org/10. 1371/journal.pone.0072169

72. Martire S, Mosca L, d'Erme M (2015) PARP-1 involvement in neurodegeneration: a focus on Alzheimer's and Parkinson's diseases. Mech Ageing Dev 146-148:53-64. https://doi.org/10.1016/j.mad.2015.04.001.

73. McGurk L, Gomes E, Guo L, Mojsilovic-Petrovic J, Tran V, Kalb RG, Shorter J, Bonini NM (2018) Poly(ADP-ribose) prevents pathological phase separation of TDP-43 by promoting liquid Demixing and stress granule localization. Mol Cell. https://doi.org/10.1016/j.molcel.2018.07.002.

74. McGurk L, Lee VM, Trojanowksi JQ, Van Deerlin VM, Lee EB, Bonini NM (2014) Poly-A binding protein-1 localization to a subset of TDP-43 inclusions in amyotrophic lateral sclerosis occurs more frequently in patients harboring an expansion in C9orf72. J Neuropathol Exp Neurol 73:837-845. https://doi.org/10.1097/NEN.0000000000000102.

75. McKeith IG, Boeve BF, Dickson DW, Halliday G, Taylor JP, Weintraub D, Aarsland D, Galvin J, Attems J, Ballard CG et al (2017) Diagnosis and management of dementia with Lewy bodies: Fourth consensus report of the DLB Consortium. Neurology 89:88-100. https://doi.org/10.1212/WNL 0000000000004058

76. Mirra SS, Heyman A, McKeel D, Sumi SM, Crain BJ, Brownlee LM, Vogel FS, Hughes JP, van Belle G, Berg $L$ (1991) The consortium to establish a registry for Alzheimer's disease (CERAD). Part II. Standardization of the neuropathologic assessment of Alzheimer's disease. Neurology 41:479-486

77. Mojsilovic-Petrovic J, Jeong GB, Crocker A, Arneja A, David S, Russell DS, Kalb RG (2006) Protecting motor neurons from toxic insult by antagonism 
of adenosine A2a and Trk receptors. J Neurosci 26:9250-9263. https://doi. org/10.1523/JNEUROSCI.1856-06.2006

78. Mojsilovic-Petrovic J, Nedelsky N, Boccitto M, Mano I, Georgiades SN, Zhou W, Liu Y, Neve RL, Taylor JP, Driscoll M et al (2009) FOXO3a is broadly neuroprotective in vitro and in vivo against insults implicated in motor neuron diseases. J Neurosci 29:8236-8247. https://doi.org/10.1523/ JNEUROSCI.1805-09.2009

79. Moroni F, Meli E, Peruginelli F, Chiarugi A, Cozzi A, Picca R, Romagnoli P, Pellicciari R, Pellegrini-Giampietro DE (2001) Poly(ADP-ribose) polymerase inhibitors attenuate necrotic but not apoptotic neuronal death in experimental models of cerebral ischemia. Cell Death Differ 8:921-932. https://doi.org/10.1038/sj.cdd.4400884

80. Morris JC, Heyman A, Mohs RC, Hughes JP, van Belle G, Fillenbaum G, Mellits ED, Clark C (1989) The consortium to establish a registry for Alzheimer's disease (CERAD). Part I. Clinical and neuropsychological assessment of Alzheimer's disease. Neurology 39:1159-1165

81. Naumann M, Pal A, Goswami A, Lojewski X, Japtok J, Vehlow A, Naujock M, Gunther R, Jin M, Stanslowsky N et al (2018) Impaired DNA damage response signaling by FUS-NLS mutations leads to neurodegeneration and FUS aggregate formation. Nat Commun 9:335. https://doi.org/10.1038/ s41467-017-02299-1

82. Nefussy B, Drory VE (2010) Moving toward a predictive and personalized clinical approach in amyotrophic lateral sclerosis: novel developments and future directions in diagnosis, genetics, pathogenesis and therapies. EPMA J 1:329-341. https://doi.org/10.1007/s13167-010-0027-0

83. Neumann M, Kwong LK, Lee EB, Kremmer E, Flatley A, Xu Y, Forman MS, Troost D, Kretzschmar HA, Trojanowski JQ et al (2009) Phosphorylation of S409/410 of TDP-43 is a consistent feature in all sporadic and familial forms of TDP-43 proteinopathies. Acta Neuropathol 117:137-149. https://doi.org/ 10.1007/s00401-008-0477-9

84. Neumann M, Kwong LK, Truax AC, Vanmassenhove B, Kretzschmar HA, Van Deerlin VM, Clark CM, Grossman M, Miller BL, Trojanowski JQ et al (2007) TDP-43-positive white matter pathology in frontotemporal lobar degeneration with ubiquitin-positive inclusions. J Neuropathol Exp Neurol 66:177-183. https://doi.org/10.1097/01.jnen.0000248554.45456.58

85. Neumann M, Sampathu DM, Kwong LK, Truax AC, Micsenyi MC, Chou TT, Bruce J, Schuck T, Grossman M, Clark CM et al (2006) Ubiquitinated TDP-43 in frontotemporal lobar degeneration and amyotrophic lateral sclerosis. Science 314:130-133. https://doi.org/10.1126/science.1134108

86. Oliver PL, Finelli MJ, Edwards B, Bitoun E, Butts DL, Becker EB, Cheeseman MT, Davies B, Davies KE (2011) Oxr1 is essential for protection against oxidative stress-induced neurodegeneration. PLoS Genet 7:e1002338. https://doi.org/10.1371/journal.pgen.1002338

87. Park EM, Cho S, Frys K, Racchumi G, Zhou P, Anrather J, ladecola C (2004) Interaction between inducible nitric oxide synthase and poly(ADP-ribose) polymerase in focal ischemic brain injury. Stroke 35:2896-2901. https://doi. org/10.1161/01.STR.0000147042.53659.6c

88. Petrov D, Mansfield C, Moussy A, Hermine O (2017) ALS clinical trials review: 20 years of failure. Are we any closer to registering a new treatment? Front Aging Neurosci 9:68. https://doi.org/10.3389/fnagi.2017.00068

89. Renton AE, Majounie E, Waite A, Simon-Sanchez J, Rollinson S, Gibbs JR, Schymick JC, Laaksovirta H, van Swieten JC, Myllykangas L et al (2011) A hexanucleotide repeat expansion in C9ORF72 is the cause of chromosome 9p21-linked ALS-FTD. Neuron 72:257-268. https://doi.org/10.1016/j.neuron. 2011.09.010

90. Rosen DR, Siddique T, Patterson D, Figlewicz DA, Sapp P, Hentati A, Donaldson D, Goto J, O'Regan JP, Deng HX et al (1993) Mutations in cu/Zn superoxide dismutase gene are associated with familial amyotrophic lateral sclerosis. Nature 362:59-62. https://doi.org/10.1038/362059a0

91. Rosenfeld J, Strong MJ (2015) Challenges in the understanding and treatment of amyotrophic lateral sclerosis/motor neuron disease. Neurotherapeutics 12:317-325. https://doi.org/10.1007/s13311-014-0332-8

92. Rothstein JD (2017) Edaravone: a new drug approved for ALS. Cell 171:725. https://doi.org/10.1016/j.cell.2017.10.011

93. Rothstein JD, Kuncl R, Chaudhry V, Clawson L, Cornblath DR, Coyle JT, Drachman DB (1991) Excitatory amino acids in amyotrophic lateral sclerosis: an update. Ann Neurol 30:224-225. https://doi.org/10.1002/ana.410300223

94. Rothstein JD, Tsai G, Kuncl RW, Clawson L, Cornblath DR, Drachman DB, Pestronk A, Stauch BL, Coyle JT (1990) Abnormal excitatory amino acid metabolism in amyotrophic lateral sclerosis. Ann Neurol 28:18-25. https:// doi.org/10.1002/ana.410280106
95. Rowland LP, Shneider NA (2001) Amyotrophic lateral sclerosis. N Engl J Med 344:1688-1700. https://doi.org/10.1056/NEJM200105313442207

96. Rulten SL, Rotheray A, Green RL, Grundy GJ, Moore DA, Gomez-Herreros F, Hafezparast M, Caldecott KW (2014) PARP-1 dependent recruitment of the amyotrophic lateral sclerosis-associated protein FUS/TLS to sites of oxidative DNA damage. Nucleic Acids Res 42:307-314. https://doi.org/10.1093/nar/ gkt835

97. Sawada $H$ (2017) Clinical efficacy of edaravone for the treatment of amyotrophic lateral sclerosis. Expert Opin Pharmacother 18:735-738. https:// doi.org/10.1080/14656566.2017.1319937

98. Saxena S, Cabuy E, Caroni P (2009) A role for motoneuron subtype-selective ER stress in disease manifestations of FALS mice. Nat Neurosci 12:627-636. https://doi.org/10.1038/nn.2297

99. Schreiber V, Dantzer F, Ame JC, de Murcia G (2006) Poly(ADP-ribose): novel functions for an old molecule. Nat Rev Mol Cell Biol 7:517-528. https://doi. org/10.1038/nrm1963

100. Shah GM, Shah RG, Poirier GG (1996) Different cleavage pattern for poly(ADP-ribose) polymerase during necrosis and apoptosis in $\mathrm{HL}-60$ cells. Biochem Biophys Res Commun 229:838-844. https://doi.org/10.1006/bbrc. 1996.1889

101. Shaw PJ, Forrest V, Ince PG, Richardson JP, Wastell HJ (1995) CSF and plasma amino acid levels in motor neuron disease: elevation of CSF glutamate in a subset of patients. Neurodegeneration 4:209-216

102. Sonnenblick A, de Azambuja E, Azim HA Jr, Piccart M (2015) An update on PARP inhibitors--moving to the adjuvant setting. Nat Rev Clin Oncol 12:2741. https://doi.org/10.1038/nrclinonc.2014.163

103. Spreux-Varoquaux O, Bensimon G, Lacomblez L, Salachas F, Pradat PF, Le Forestier N, Marouan A, Dib M, Meininger V (2002) Glutamate levels in cerebrospinal fluid in amyotrophic lateral sclerosis: a reappraisal using a new HPLC method with coulometric detection in a large cohort of patients. J Neurol Sci 193:73-78

104. Sreedharan J, Blair IP, Tripathi VB, Hu X, Vance C, Rogelj B, Ackerley S, Durnall JC, Williams KL, Buratti E et al (2008) TDP-43 mutations in familial and sporadic amyotrophic lateral sclerosis. Science 319:1668-1672. https:// doi.org/10.1126/science.1154584

105. Takahashi K, Greenberg JH, Jackson P, Maclin K, Zhang J (1997) Neuroprotective effects of inhibiting poly(ADP-ribose) synthetase on focal cerebral ischemia in rats. J Cereb Blood Flow Metab 17:1137-1142. https:// doi.org/10.1097/00004647-199711000-00001

106. Tan RH, Yang Y, Kim WS, Dobson-Stone C, Kwok JB, Kiernan MC, Halliday GM (2017) Distinct TDP-43 inclusion morphologies in frontotemporal lobar degeneration with and without amyotrophic lateral sclerosis. Acta Neuropathol Commun 5:76. https://doi.org/10.1186/s40478-017-0480-2

107. Taylor JP, Brown RH Jr, Cleveland DW (2016) Decoding ALS: from genes to mechanism. Nature 539:197-206. https://doi.org/10.1038/nature20413

108. Thal DR, Rub U, Orantes M, Braak H (2002) Phases of a beta-deposition in the human brain and its relevance for the development of AD. Neurology 58:1791-1800

109. Turunc Bayrakdar E, Uyanikgil Y, Kanit L, Koylu E, Yalcin A (2014) Nicotinamide treatment reduces the levels of oxidative stress, apoptosis, and PARP-1 activity in Abeta(1-42)-induced rat model of Alzheimer's disease. Free Radic Res 48:146-158. https://doi.org/10.3109/10715762.2013. 857018

110. Uryu K, Nakashima-Yasuda H, Forman MS, Kwong LK, Clark CM, Grossman M, Miller BL, Kretzschmar HA, Lee VM, Trojanowski JQ et al (2008) Concomitant TAR-DNA-binding protein 43 pathology is present in Alzheimer disease and corticobasal degeneration but not in other tauopathies. J Neuropathol Exp Neurol 67:555-564. https://doi.org/10.1097/ NEN.0b013e31817713b5

111. Van Den Bosch L, Van Damme P, Bogaert E, Robberecht W (2006) The role of excitotoxicity in the pathogenesis of amyotrophic lateral sclerosis. Biochim Biophys Acta 1762:1068-1082. https://doi.org/10.1016/j.bbadis.2006. 05.002

112. Vance C, Rogelj B, Hortobagyi T, De Vos KJ, Nishimura AL, Sreedharan J, Hu X, Smith B, Ruddy D, Wright P et al (2009) Mutations in FUS, an RNA processing protein, cause familial amyotrophic lateral sclerosis type 6. Science 323:1208-1211. https://doi.org/10.1126/science.1165942

113. Wang Y, An R, Umanah GK, Park H, Nambiar K, Eacker SM, Kim B, Bao L, Harraz MM, Chang C et al (2016) A nuclease that mediates cell death induced by DNA damage and poly(ADP-ribose) polymerase-1. Science 354. https://doi.org/10.1126/science.aad6872 
114. Wang Y, Kim NS, Haince JF, Kang HC, David KK, Andrabi SA, Poirier GG, Dawson VL, Dawson TM (2011) Poly(ADP-ribose) (PAR) binding to apoptosis-inducing factor is critical for PAR polymerase-1-dependent cell death (parthanatos). Sci Signal 4:ra20. https://doi.org/10.1126/scisignal. 2000902

115. Yokoyama H, Kuroiwa H, Tsukada T, Uchida H, Kato H, Araki T (2010) Poly(ADP-ribose)polymerase inhibitor can attenuate the neuronal death after 1-methyl-4-phenyl-1,2,3,6-tetrahydropyridine-induced neurotoxicity in mice. J Neurosci Res 88:1522-1536. https://doi.org/10.1002/jnr.22310

116. Zhang J, Dawson VL, Dawson TM, Snyder SH (1994) Nitric oxide activation of poly(ADP-ribose) synthetase in neurotoxicity. Science 263:687-689

117. Zhang K, Daigle JG, Cunningham KM, Coyne AN, Ruan K, Grima JC, Bowen KE, Wadhwa H, Yang P, Rigo F et al (2018) Stress Granule Assembly Disrupts Nucleocytoplasmic Transport. Cell 173:958-971 e917. https://doi.org/10. 1016/j.cell.2018.03.025

Ready to submit your research? Choose BMC and benefit from:

- fast, convenient online submission

- thorough peer review by experienced researchers in your field

- rapid publication on acceptance

- support for research data, including large and complex data types

- gold Open Access which fosters wider collaboration and increased citations

- maximum visibility for your research: over $100 \mathrm{M}$ website views per year

At $\mathrm{BMC}$, research is always in progress.

Learn more biomedcentral.com/submissions 